2. To: (Receiving organization)

WHC WESF Engineering

5. Proj./Prog./Dept./Div.:

16E20

8. Originator Renarks:

This document describes the actions taken to confirm and respond to a very small $(0.046 \mathrm{mT} / \mathrm{min})$ leak in the

staintess steel liner of Hanford's Waste Encapsulation and Storage Facility (WESF) storage pool cell 5 in

Building $225=\mathrm{B}$

11. Receiver Remarks:
3. From: (Originating organization) WHC WESF Engineering

J. H. E. Rasmussen
6. Cog. Engr.:

4. Related EDT NO.:

$\mathrm{N} / \mathrm{A}$

7. Purchase Order No.:

N/A

9. Equip./Component No.:

$\mathrm{N} / \mathrm{A}$

10. Systen/Bldg./Facility:

Capsule storage

Basins/225-B/WESE

12. Major Assm. DWg. No.:

$\mathrm{N} / \mathrm{A}$

13. Permit/Permit Application No.: N/A

14. Required Response Date:

$\mathrm{N} / \mathrm{A}$

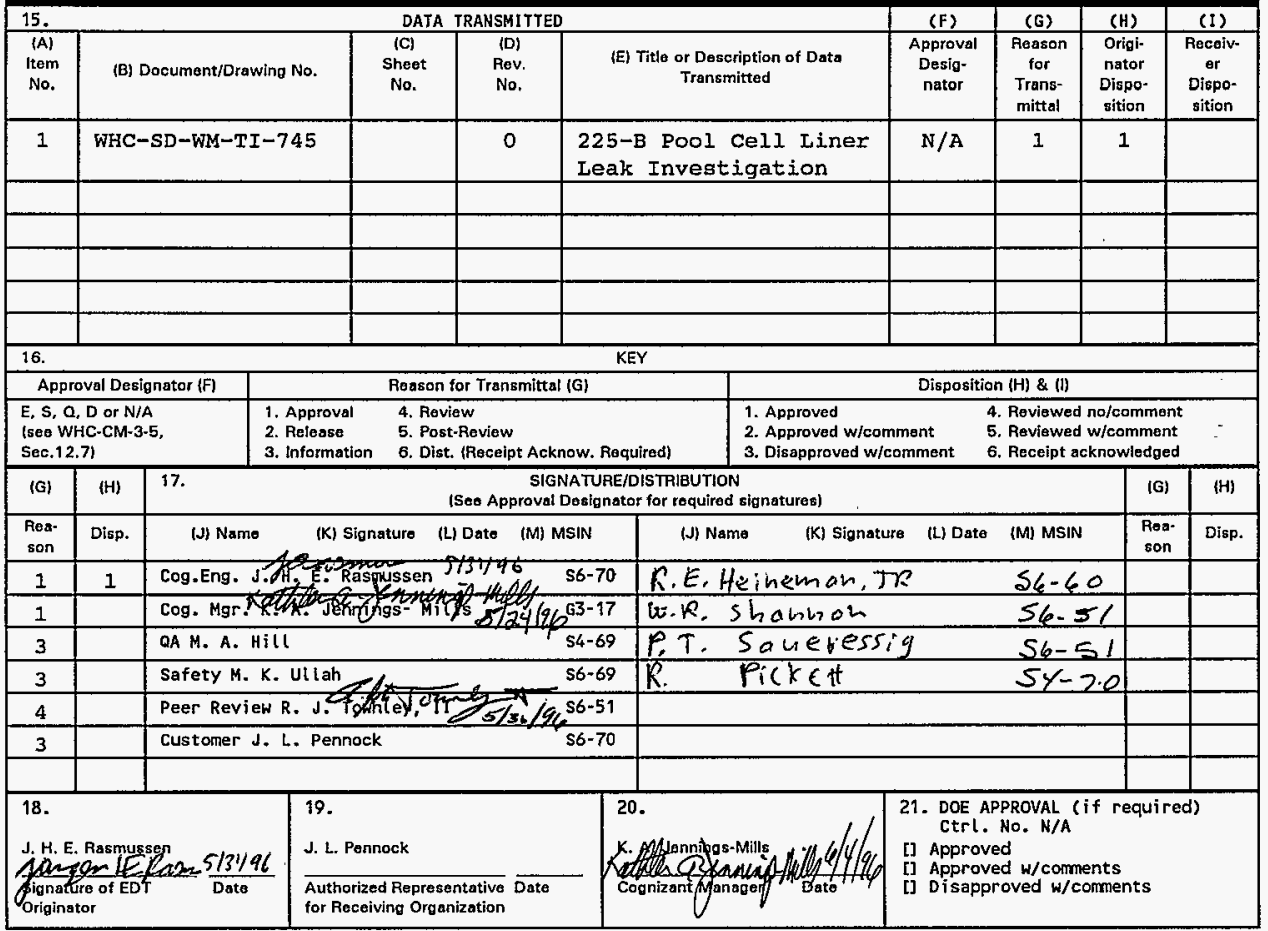




\title{
225-B Pool Cell 5 Liner Leak Investigation
}

\author{
Juergen H. E. Rasmussen \\ Westinghouse Hanford Company, Richland, WA 99352 \\ U.S. Department of Energy Contract DE-AC06-87RL10930 \\ EDT/ECN: $\quad 610969$ \\ Org Code: 16Е20 \\ B\&R Code: EW3135090 \\ UC: 510 \\ Charge Code: KWWL1 \\ Total Pages: 55 fa $5 / 31 / 96$ \\ Key Words: WESF, 225-B, Pool Cell, Liner, Leak
}

Abstract: This document describes the actions taken to confirm and respond to a very small $(0.046 \mathrm{ml} / \mathrm{min})$ leak in the stainless steel liner of Hanford's Waste Encapsulation and Storage Facility (WESF) storage pool cell 5 in Building 225-B. Manual level measurements confirmed a consistent weekly accumulation of 0.46 liters of water in the leak detection grid sump below the pool cell 5 liner. Video inspections and samples point to the capsule storage pool as the source of the water. The present leak rate corresponds to a decrease of only 0.002 inches per week in the pool cell water level, and consequently does not threaten any castrophic loss of pool cell shielding and cooling water. The configuration of the pool cell liner, sump system, and associated risers will limit the short-term consequences of even a total liner breach to a loss of 1 inch in pool cell level. The small amount of demineralized pool cell water which has been in contact with the concrete structure ig not enough to cause significant structural damage. However, ongoing monitoring is crucial so that the facllity can respond appropriately if water-concrete interaction increases. The pool cell leak detection sump instrumentation will be modified to improve monitoring of the leak rate in the future. Weekly manual sump level measurements continue in the interim. Contingency plans are in place to relocate the pool cell 5 capsules if the leak worsens.

TRADEMARK DISCLAIMER. Reference herein to any specific comercial product, process, or service by trade name, trademark, manufacturer, or otherwise, does not necessarily constitute or imply its endorsement, recommendation, or favoring by the United States Government or any agency thereof or its contractors or subcontractors.

Printed in the United States of America. To obtain copies pf this dogument contact: WHC/BCS Document Control Services, P.O. Box 1970, Mailstop H6-08, R chland WA 99352, PFione (50) $372-2^{4} 420$, Fax (509) 376-4989.
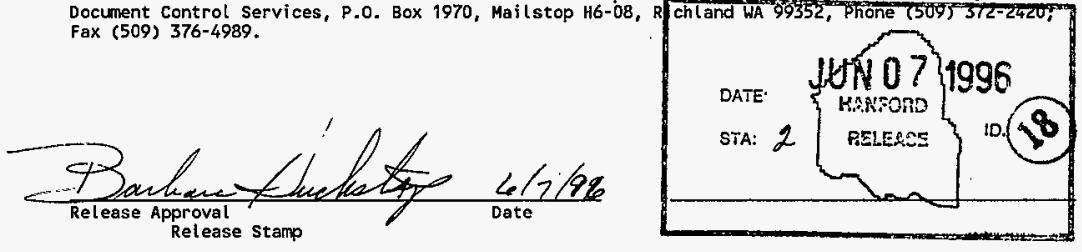

Approved for Public Release 


\section{5-B Pool Cell 5 Liner Leak Investigation}

WHC-SD-WM-TI-745

Rev. 0

J. H. E. Rasmussen

Westinghouse Hanford Company

March 1996 
1.0 INTRODUCTION . . . . . . . . . . . . . . . . . . . 3

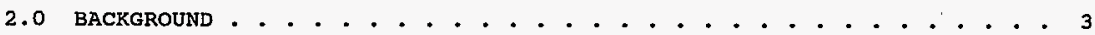

2.1 Configuration of Pool cell Liner Leak Detection System . . . . 3

2.2 Periodic Leak Detector Testing . . . . . . . . . . . . . 6

2.3 Pool Cell 5 sump Alarms . . . . . . . . . . . . . . 6

3.0 ACTIONS TAKEN TO DATE . . . . . . . . . . . . . . . . . . . . 7

3.1 Actions Taken to Identify the Leak Source $\quad$. . . . . . . . . 7

3.2 Actions Taken to Evaluate Implications on Safe Capaule Storage . . 9

3.3 Actions Taken to Ensure Continued Safe Capsule storage . . . . . 18

4.0 CURRENT STATUS . . . . . . . . . . . . . . . . . . . . 20

4.1 Status of Pool cell 5 . . . . . . . . . . . . . . . . . 20

4.2 Status of Occurrence Report Actions . . . . . . . . . . . . . 20

4.3 Status of Actions Identified in Plant Review Committee Meeting . . 21

5.0 FOLLOW-ON ACTIONS . . . . . . . . . . . . . . . . . 22

6.0 APPENDIX . . . . . . . . . . . . . . . . . . . 23

6.1 Sump Level Measurements . . . . . . . . . . . . . . . 23

6.2 Sump Video Ingpection Results . . . . . . . . . . . . 26

6.3 Interviews with Plant Personnel ............... . 44

\section{LIST OF TABLES}

Table 3.1.1 Pool Cell sump Sample Regults and Comparison . . . . . . . 8 Table 3.2.2 wESF pool Cell Evaporation Rates . . . . . . . . . . . . 11

Table 3.3.1 Alternate Capsule storage Options . . . . . . . . . . 19

Table 6.1.1 Pool Cell 5 sump Levels, Inches . . . . . . . . . . . 23

Table 6.1.2 pool cell 1 and 2 sump Levels, Inches . . . . . . . . . . 24

Table 6.1.3 pool Cell 3-4, 6-8, and 12 Sump Levels, Inches........ 24

Table 6.1.4 pool cell 9-11 sump Levels, Inches.............. 25 


\section{LIST OF FIGURES}

FIGURE 2.1.1 WESF Pool Cell Typical sump Arrangement . . . . . . . . . 4

Figure 3.2.1

Figure 3.2.2

FIGURE 6.2.1

FIGURE 6.2 .2

FIGURE 6.2.3

FIGURE 6.2.4

FIGURE 6.2.5

FIGURE 6.2 .6

FIGURE 6.2 .7

FIGURE 6.2.8

FIGURE 6.2.9

FIGURE $\mathbf{6 . 2 . 1 0}$

FIGURE 6.2.11

FIGURE 6.2.12

FIGURE 6.2 .13

FIGURE 6.2.14

FIGURE 6.2 .15

FIGURE 6.2.16

FIGURE 6.2.17

FIGURE 6.2 .18

FIGURE 6.2 .19

FIGURE 6.2 .20

FIGURE 6.2.21

FIGURE 6.2 .22

F IGURE 6.2 .23

FIGURE 6.2 .24

FIGURE 6.2 .25

FIGURE 6.2.26
Pool Cell 5 sump Level Measurements............... 10

Pool cell 1-12 sump levels ................. . 15

WESF Pool cell 5 sump overall view . . . . . . . . . 28

WESF Pool Cell 5 Liner Drain Grid Outfall Pipe . . . . . 28

WESF Pool Cell 1 Liner Drain Grid outfall Pipe . . . . . . . 29

WESF pool cell 1 sump Below Drain Grid Outfall . . . . . 29

WESF Pool Cell 2 Liner Drain Grid Outfall Pipe . . . . . . 30

WESF Pool Cell 2 sump Below Drain Grid Outfall . . . . . . 30

WESF Pool cell 3 sump overall view . . . . . . . . . . . 31

WESF Pool Cell 3 Iiner Drain Grid outfall Pipe . . . . . . 31

WESF Pool cell 4 Iiner Drain Grid Outfall Pipe . . . . . . 32

WESF Pool Cell 4 sump Below Drain Grid outfall . . . . . . 32

WESF pool Cell 6 sump overall view . . . . . . . . . . 33

WESF Pool Cell 6 sump Jet out Pipe ............ . 33

WESF Pool Cell 7 Liner Drain Grid Outfall Pipe . . . . . . 34

WESF Pool Cell 7 sump Below Drain Grid outfall . . . . . . . 34

WESF Pool cell 8 sump overall view . . . . . . . . . . . 35

WESF Pool Cell 8 Liner Drain Grid Outfall Pipe..... . . 35

WESF Pool cell 9 Sump overall view ........... 36

WESF Pool cell 9 Liner Drain Grid outfall Pipe . . . . . . 36

WESF Pool Cell 10 sump overall view . . . . . . . . . 37

WESF Pool cell 10 Liner Drain Grid Outfall Pipe . . . . . 37

WESF Pool cell 11 sump overall view . . . . . . . . 38

WESF Pool Cell 11 Liner Drain Grid outfall Pipe . . . . . 38

WEsF Pool cell sump 12-1 overall view . . . . . . . . 39

WESF Pool Cell sump 12-1 Drain Grid outfall Pipe. . . . . 39

WESF pool Cell sump 12-2 overall view .......... 40

WESF Pool Cell Sump 12-2 Drain Grid Outfall pipe From South

Portion of Transfer Aisle ....................440

FIGURE 6.2.27 WESF Pool Cell Sump 12-2 Drain Grid outfall Pipe From Cask pit

FIGURE 6.2.28 WESF POOI Cell Sump 12-2 Dxain Grid Outfall Pipe From Cask Pit-

Closeup

FIGURE 6.2 .29

FIGURE 6.2 .30

FIGURE 6.2.31
....................... . 41

WESF POOl Cell 1 sump Ceiling (Upward) . . . . . . . . . 42

WESF Pool Cell 6 Bottom of 6-Inch Leak Detector Riser . . . 42

WESF Pool Cell 7 Top of 6-Inch Leak Detection Riser (Downward)

FIGURE 6.2.32 WESE Pool Cell sump 12-2 Jet out line . . . . . . . . . . . 43 


\subsection{INTRODUCTION}

The Wagte Encapgulation and storage Facility (WESF), located in the 200East area of the Hanford site, is tasked with the mission of safely storing 72 milion curies of encapsulated purified fission products. These fission. product capsules are stored underwater in stainless steel-lined pool cells for radiological shielding and thermal cooling. Drainage collection troughs underneath each pool cell liner route any leakage to stainless steel gumps equipped with leak detectors. The leak detectors are tested every 6 months by adding water to the sumps, verifying actuation of the associated alarm, and then removing the sump contents. Sodium nitrate solution is added to the sumps to provide sufficient electrical conductivity to operate the conductivity leak detectors.

Approximately 0.47 literg per week of water seeps into the leak detection sump associated with WESF pool cell 5. This water accumulation was identified as the cause of repeated leak detection sump alarms trips (ref. RL--WHCBPLANT-1995-0037). The source of this water appears to be a leak in the pool cell 5 liner. Pool cell 5 containg nominally 34,000 liters of demineralized cooling/shielding water. The current leak rate corresponds to a $0.05 \mathrm{~mm}$ (0.002 inch) per week level decreage in pool cell 5. This leak rate is leas than 1 \& of the routine evaporation logses, and hence does not threaten capsule cooling and shielding capabilities. This report documents the background of the leak, actions taken, current status, and follow-on actions to deal with this situation.

\subsection{BACKGROUND}

\subsection{Configuration of Pool Cell Liner Leak Detection System}

Figure 2.1.1, below, shows the general arrangement of the pool cell 5 liner, leak collection grid, sump, and detection system. Further details are shown on drawings H-2-66427, "STRUCTURAL IINER PLATE DETAILS," H-2-66422, "STRUCTURAL SECTIONS AREA 3," H-2-67019, "POOL CELI SECTIONS AND DETAILS," H-2-66428, "STRUCTURAL AREAS 2 AND 3," H-2-67018, "POOL CELI EQUIPMENT AND PIPING ARRANGEMENT," H-2-66659, "INSTRUMENTATION POOL CELL ELEVATIONS AND INSTALLATION DETAILS," and H-2-66421, "STRUCTURAL FOUNDATION \& FLOOR PLANAREA \#3." 
4

WHC-SD-WM-TI-745

Rev. 0

FIGURE 2.1.1 WESF Pool Cell Typical Sump Arrangement

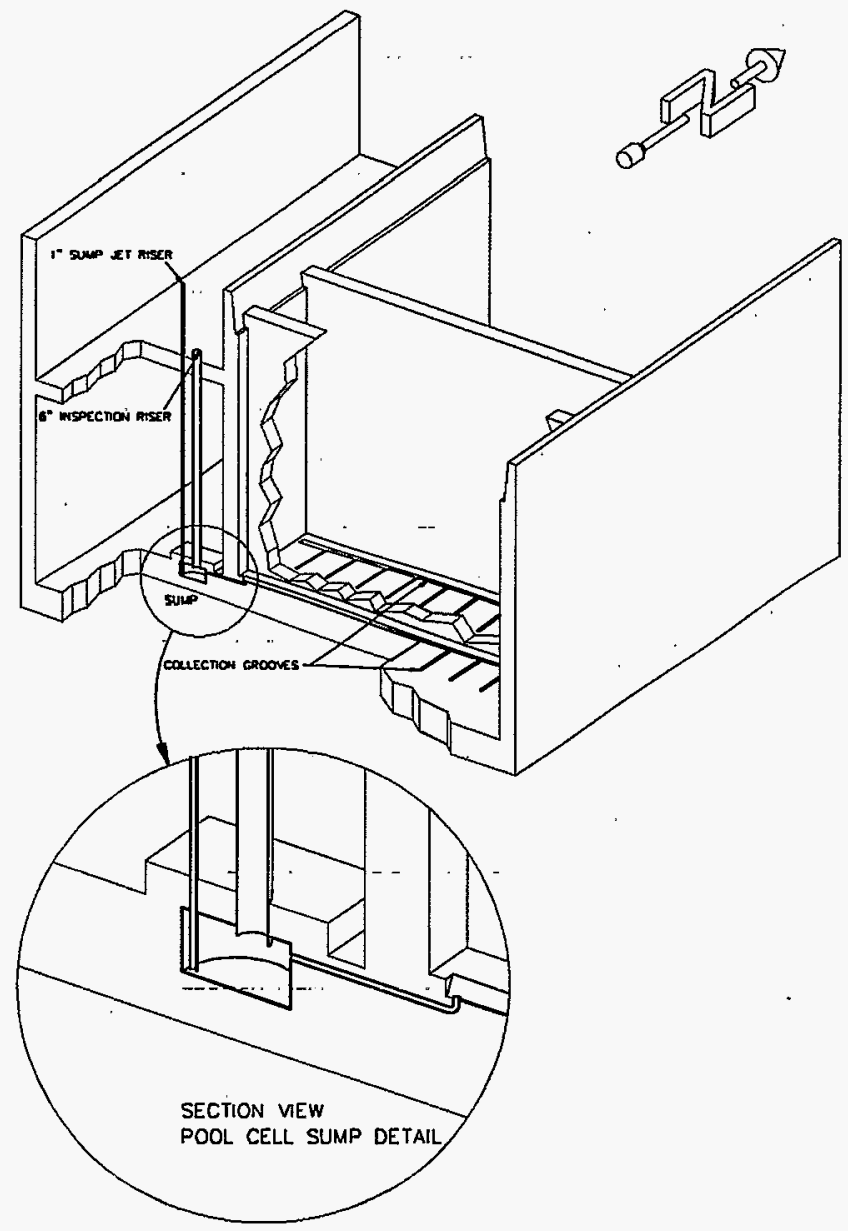


The WESF pool cells, the transfer aisle, and the cask pit are reinforced concrete basins lined with stainless steel. A drain grid, consisting of a network of concrete troughs, is located below the liner of each pool cell, the cask pit, and the transfer aisle. Each drain grid slopes toward a 1-inch stainless steel pipe, which terminates in a 12-inch high sealed stainless steel sump chamber. The sump chambers are constructed of 20-inch schedule 10 pipe oriented vertically, sealed with plateg welded onto the top and bottom. The liner drain grid outfall into each sump is 9 inches above the bottom of the sump. Each sump is equipped with a 1-inch jet-out line and a 6-inch leak detector mounting riger. The jet-out lines terminate 1 inch above the bottom of each sump. Normally, the jet-out riser is sealed with a blind flange, and the leak detection riser is sealed by the installed leak detector. The leak detectors are electrical conductivity sensors suspended 3 inches above the bottoms of the sumps.

Transfer aigle sumps $12-1$ and 12-2 differ only slightly from the sumps associated with pool cells 1-11. The elevations of the sumps and the routing of the 1-inch drain grid outfall and jet-out pipes also differ to accommodate the location of the drain grids. Otherwise, the diameter, height, and general configuration of the transfer aisle sumps is similar to the other pool cell sumps. Sump 12-1 is located to the east of the transfer aisle, which adjoins the east walls of pool cells 1-11. Sump 12-2 is located south of pool cell 1, and west of the cask pit. A drain grid beneath the northern portion of the transfer aisle drains to sump 12-1. Sump $12-2$ is connected to two drain grids. The northernmost pipe entering sump 12-2 is the outfall from the drain grid beneath the southern portion of the transfer aisle. The southernmost pipe entering the side of sump $12-2$ is the outfall from the drain grid below the cask pit.

Pool cells $1-8$ and the transfer aisle are filled with non-radioactive demineralized water for capsule cooling and/or shielding. Pool cells 3, 4, 5, 6, and 7 are currently active capsule storage pools, meaning that fission product capsules are now stored therein. Capsules are moved to and from the other pool cells via the transfer, aisle, but no capsules are stored there. Pool cell 1 is equipped for capsule storage, but does not currently contain capsules. Pool cells 2 and 8 are filled with water for shielding purposes, but are not fully equipped for capsule storage. Pool cells 9 and 10 are being used to collect non-radioactive, non-hazardous waste water which originates from sources such as HVAC steam condensate, pump packing glands, etc. Pool cell 11 is dry, and houses an ion exchange system. 


\subsection{Periodic Leak Detector Testing}

Periodically, the leak detection systems are tested by adding demineralized water via the jet-out risers. After proper activation of the alarm is confirmed, a steam jet is connected to the jet-out riser, and the sump contents are removed. A cup of sodium nitrate solution is then added via the jet-out riser. The sodium nitrate provides sufficient ions to ensure that the leak detector will respond to demineralized water leaking from the pool cell. The jet-out riser is re-sealed after completion of the periodic test.

\subsection{Pool Cell 5 sump Alaxms}

The leak detector under WESF pool cell 5 has had a long history of alarming between periodic tests. In the past the alarm was cleared by jetting out the sump and performing a function check of the leak detector. It became obvious as early as January 1995 that the alarm panel remained in alarm more than it was cleared. With operations assistance and craft support the alarm was cleared several times during 1995. When it became apparent to all that the alarm would re-annunciate within a relatively short time after being cleared, a work package was initiated to remove the leak detector, compare against specifications for performance and installation, repair or replace parts as needed, inspect the sump using a video camera, and replace the leak detector after repairing the problem.

At no point in the thought process or discussions with operations and maintenance personnel was any credibility given to the possibility of a leak in the liner. There are several reasons for this:

- No significant quantity of water (more than operating the jet for a matter of seconds to remove) was reported as found whenever the sump was emptied.

- Neither anomalous decreases in the pool cell 5 level indication (weight factor readings) nor unusual water additions were noted on any surveillance data sheets.

- The sump alarm did not recur predictably, which did not suggest a constant leak rate as would be expected given the constant conditions of the pool cell such as temperature and liquid level. 


\subsection{ACTIONS TAKEN TO DATE}

The actions taken to date began with instrument troubleshooting to investigate the cause of repeated pool cell 5 sump alarms. The leak detector was removed and inspected per work package 2B-95-0064. The configuration and performance of the detector matched the design specifications per drawing H-266659, "INSTRUMENTATION POOL CELL ELEVATIONS AND INSTALIATION DETAILS." An occurrence (RL--WHC-BPLANT-1995-037) was declared on 8/18/95 when it was determined from sump level measurements that water was accumulating in the pool cell 5 leak detector sump. An Unreviewed Safety Question (USQ) screening of this potential discovery was performed. Action plans identified in the Occurrence Report and in the plant Review committee (PRC) meeting which reviewed the USQ screening have largely been completed as described in the following sections of this report. The focus of these action plans was threefold:

- To identify the source of the leak.

- To evaluate the implications, if any, on safe capsule storage.

- To take actions as required to ensure the continued safety of capaule storage at WESF.

\subsection{Actions Taken to Identify the Leak Source}

The source of the water was not immediately apparent. The most obvious candidate, in terms of the number of welds and other potential leak points, was a leak of pool cell water via a hole or crack in the pool ceil liner. A direct path to the leak detection sump could also exist for a leak in a raw water line penetrating the liner. Sanitary water is present in the pool cell area but no sanitary water piping enters the pool cell itself nor penetrates the liner.

The source of the water accumulating in the pool cell 5 leak detector sump was identified as pool cell demineralized water by sampling. The leak detector sump was sampled on september 1, 1995. Sample R-7709 was obtained from the pool cell 5 leak detector sump on september 1, 1995 and analyzed at the 222-s laboratory. Table 3.1.1, below, compares the results of sample R-7709 with raw and sanitary water analyses supplied by the water utilities organization, and with sample R-7710 of the demineralized water in pool cell 5 . 
Table 3.1.1 Pool Cell sump Sample Results and Comparison

\begin{tabular}{|c|c|c|c|c|c|}
\hline $\begin{array}{l}\text { Analysis (ppm } \\
\text { except for } \mathrm{pH} \text { ) }\end{array}$ & $\begin{array}{c}\text { Pool Cell } 5 \text { sump } \\
\text { Sample R7009 }\end{array}$ & $\begin{array}{l}\text { Pool Cell } 5 \\
\text { Sample R7010 }\end{array}$ & $\begin{array}{l}\text { Raw } \\
\text { Water }\end{array}$ & $\begin{array}{l}\text { Sanitary } \\
\text { Water }\end{array}$ & \\
\hline $\mathrm{pH}$ & 8.38 & 6.31 & 7.00 & 7.00 & (a) \\
\hline Al & 0.83 & $<0.05$ & $0.18 \quad b$ & ND & \\
\hline B & 0.21 & $<0.05$ & ND & ND & \\
\hline $\mathrm{Ca}$ & 3.44 & $<0.10$ & $19.02 \mathrm{C}$ & 17.00 & (a) \\
\hline $\mathrm{Cr}$ & 0.02 & $<0.01$ & $<10 \quad b$ & $<0.005$ & (d) \\
\hline $\mathrm{Na}$ & 363.00 & 0.18 & $2.23 \quad \mathrm{~b}$ & 2.10 & (a) \\
\hline $\mathrm{Ba}$ & $<0.05$ & $<0.05$ & $0.0029 \mathrm{~b}$ & ND & \\
\hline $\mathrm{Mg}$ & $<0.10$ & $<0.10$ & $4.50 \quad c$ & 3.93 & (a) \\
\hline $\mathrm{K}$ & 16.00 & $<0.5$ & $0.80 \quad \mathrm{c}$ & 0.80 & (a) \\
\hline si & 5.22 & 1.40 & 2.90 & 3.60 & (a) \\
\hline $\mathrm{Cl}$ & 6.56 & 0.10 & $1.00 \quad \mathrm{c}$ & 1.00 & (a) \\
\hline No3 & 979.00 & $<0.7$ & $<1.00 \mathrm{c}$ & 0.40 & (a) \\
\hline SO4 & $<0.746$ & $<0.678$ & $9.00 \quad \mathrm{c}$ & 8.00 & (a) \\
\hline $\begin{array}{l}\text { Grace Dea } \\
\text { WHC-EP-03 } \\
\text { Grace Dea } \\
\text { HEHF-96, } \\
\text { Not Deter }\end{array}$ & $\begin{array}{l}\text { rborn, laboratory } \\
42 \text {, Addendum } 7 \text { dat } \\
\text { rborn, laboratory } \\
\text { "Hanford Sanitary } \\
\text { nined }\end{array}$ & $\begin{array}{l}\text { no. } 95-08084 \\
\text { ta for } 200 \text { w } \\
\text { no. } 95-08393 \\
\text { water qualit }\end{array}$ & $\begin{array}{l}\text { ID no. } 6 \\
\text { aw water, } \\
\text { ID NO. } 2 \\
\text { Surveill }\end{array}$ & $\begin{array}{l}017002 \\
\text { able } 3-1 \\
0170072 \\
\text { nce," } 1995\end{array}$ & \\
\hline
\end{tabular}

The sump contains much less calcium, magnesium, and sulfate than is present in raw or sanitary water. Therefore raw and sanitary water must be ruled out as possible sources of the sump contents. The sump contains higher levels of aluminum, calcium, and silica than the pool cell water. Aluminum, calcium, and silica are major constituents of Portland cement, and would be leached from concrete by contact with demineralized water. The stoichiometric proportions of sodium and nitrate in the sump sample are consistent with the routine additions of sodium nitrate electrolyte during leak detector testing. 
Video inspection confirmed that the path of water entering the sump is via the drain grid outfall pipe. The leak detection sump was inspected using a video camera inserted into the leak detector mounting riser. As shown in Figures 6.2.1, and 6.2.2, a prominent white stalactite indicates a long-term slow leak from the drain grid collection pipe outfall into the sump. Water droplets hang from the ceiling of the sump, indicating that water evaporates, condenses, and drains back to the sump within the sealed sump cavity. White crystalline debris elsewhere in the sump may be sodium nitrate residues.

\subsection{Actions Taken to Evaluate Implications on Safe Capsule Storage}

A leak in the pool cell liner could affect safe capsule storage in several ways. Periodic sump level measurements were used to estimate the leak rate and ruled out any immediate threat of loss of capsule cooling/shielding water. Video inspections of the other pool cell sumps confirmed that the pool cell 5 liner leak is an isolated case and that similar failures are not occurring on the other pool cells. A review of the leak rates and water chemistry concluded that any structural damage resulting from the presence of demineralized water outside the pool cell liner envelope is negligible.

Manual sump level measurements showed that the leak rate is a scant 0.47 liters per week, or only $0.047 \mathrm{ml} / \mathrm{minute}$, or enough to cause an insignificant 0.002 inch pool cell 5 level drop per week. The sump level was measured manually through the leak detector mounting riser. The measurement technique consisted of inserting a PVC pipe with a piece of high density cardboard attached to indicate the liquid level. Figure 3.2.1 shows the sump level measurements to date. Raw sump level data are presented in Table 6.1.1.

Iinear interpolation of the data from september 18, 1995 through May 1, 1996 indicates 0.47 liters of liquid draining into the sump per week. The volumetric leak rate was computed by first multiplying the level data by the internal cross sectional area of the 20-inch schedule 10 sump, less the metal cross-sectional area of the 1-inch schedule 40 sump jet-out line. A leastsquares linear interpolation of the resulting volume versus time data was then performed to estimate the time rate of change of the volume of the sump contents. 


\section{Figure 3.2.1 Pool Cell 5 sump Level Measurements}

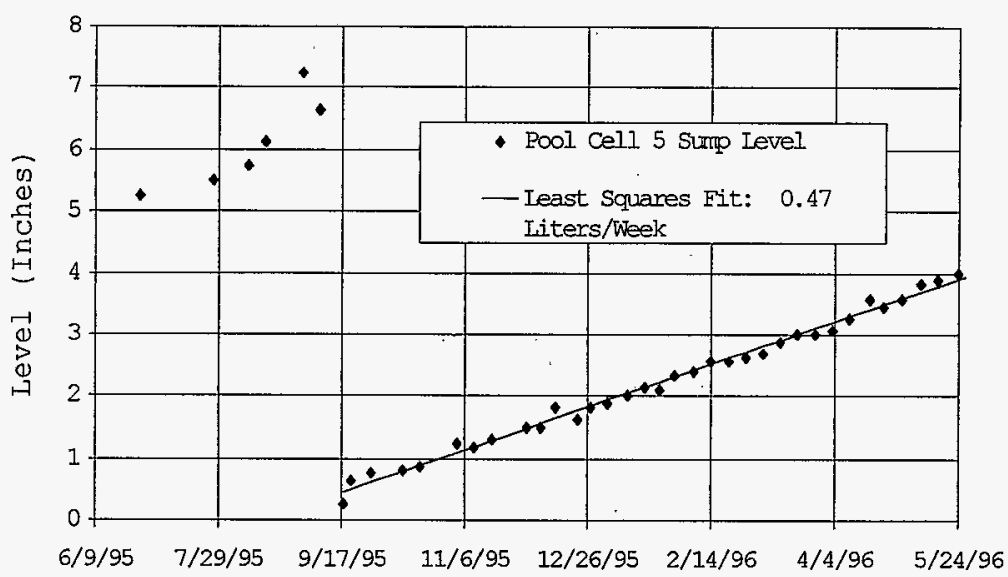

Date of Measurement

To put the observed leak rate in perspective, a comparison with routine evaporation losses showed that the liner leak rate is not only less than $1 \%$ of routine evaporation losses, the liner leak rate is non-detectable with the pool cell level instruments used to guide routine water additions to the pool.

WESF pool cells 1-7 and the transfer aisle (pool cell 12), are open to the pool cell room atmosphere, and require periodic water additions to replace water lost through evaporation. The amount of water required varies from pool to pool, due to the varying radioactive decay heat loads, and, hence, water temperatures. Water temperatures vary with the seasons in response to seasonal changes in the cooling water supply temperatures. Lastly, additional variations result from weather-related changes in the humidity of the air supplied to the storage pool area.

Pool cell levels are recorded twice per shift. The pools are topped off with demineralized water as needed, typically once a week. Evaporation rates can be computed from the gradual decline in water levels between water 
additions to the pools, and the cross sectional areas of the individual pool cells.

During 1995, the maximum observed pool cell 5 water loss rate was approximately 1 inch, or 60 gallons, per week. For comparison, the computed 0.47 liter/week water accumulation rate in the pool cell 5 sump corresponds to 0.002 inches of water level in the pool cell. The pool cell water level is displayed to a resolution of 0.1 inches. This small rate of water drainage to the sump is not detectable by the pool cell level ingtruments.

Table 3.2.2, below, ghows how pool cell water levels typically vary with time in late summer. Water loss is principally by evaporation, but minor pump packing leaks, sample collections, etc, also contribute to the gradual loss of water from the storage pools. It is clear from Table 3.3.1, that pool cell 5, which has a heat load similar to that of pool cell 4, but less than that of pool cells 3 and 6 , show no evidence of anomalous liquid losses. The weekly changes in weight factor and liquid levels are computed from linear interpolation of the weight factor data versus time.

Table 3.2.2 WESF Pool Cell Evaporation Rates

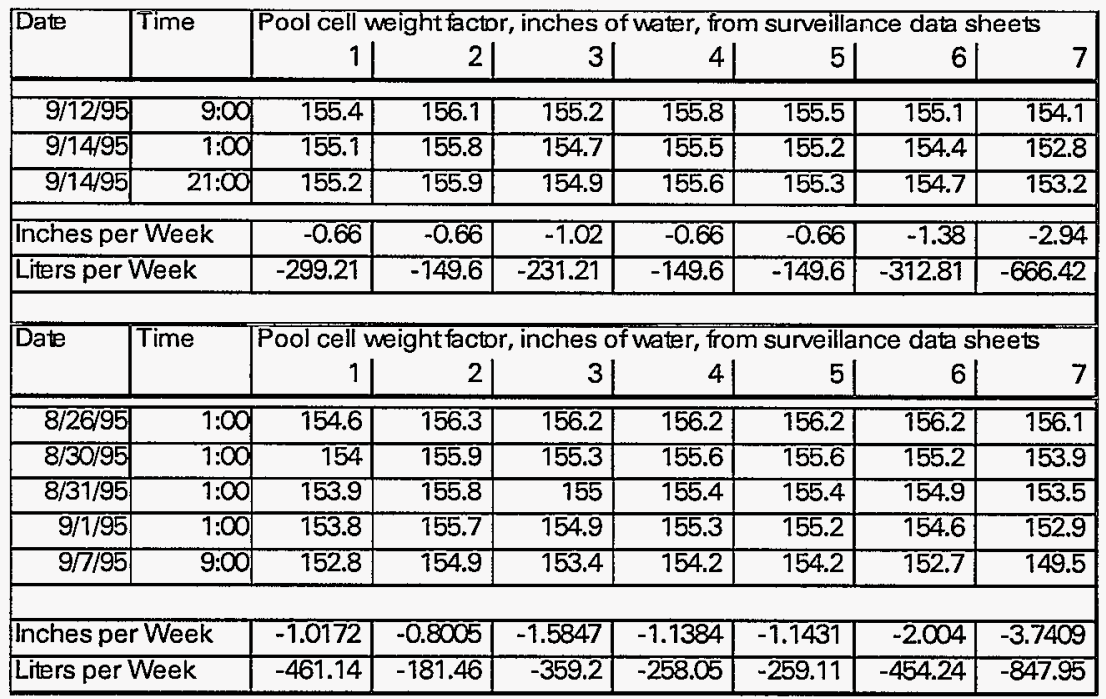


In order to determine whether the leak in pool cell 5 was an isolated case, video inspections similar to that performed in the pool cell 5 sump were conducted in all the other pool cell sumps, namely those associated with pool cells $1,2,3,4,6,7,8,9,10$, and 11 , and transfer aisle sumpg $12-1$ and 12-2. Figures 6.2 .3 through 6.2 .32 show representative views of each sump. Each sump video shows crystals, crusts, and/or stalactites at the respective drainage line outfalls, but not to the extent seen in pool cell 5. Crystalline reaidues from sodium nitrate ( $\mathrm{NaNO}_{3}$ ) electrolyte additions and periodic water additions for testing obscure evidence of leakage.

Video inspections of the pool cell sumps are recorded on videotapes \#2001465, 200-1466, 200-1467, and 200-1468 archived by the wHC surveillance Systems Integration organization. Figure 6.2.1 shows the outfall of the 1inch pipe which routes the pool cell 5 liner drainage grid into the side of the 20-inch sump. Deposits in and extending downward from the 1-inch pipe show that a slow leak has existed in pool cell 5 for a considerable length of time. Figure 6.2.2 shows the white-colored deposit on the bottom of the 1inch outfall pipe in greater detail.

For comparison, Figures 6.2.3, through 6.2 .32 show the condition of sumps beneath pool cells $1,2,3,4,6,7,8,9,10,11$, and 12 , including both of the sumps servicing the transfer aisle (pool cell 12). Except for sump 12-2, these sumps are similar in construction to the pool cell 5 sump. Sump 12-2 is similar to the others except that it collects water from two separate drainage grids. The left-hand pipe in Figure 6.2 .25 is the outfall from the drainage grid beneath the southern portion of the transfer aisle. The right-hand pipe in Figure 6.2.25 is the outfall from the drain grid under the cask pit. It is interesting to note the differences in appearance and weld details between the two outfall pipes entering pool cell sump 12-2. It appears that the weld attaching the northernmost outfall pipe entering sump 12-2 is on the outside surface of the sump vessel, while the weld beads for the other outfall pipes are on the ingide surface of the respective sump vegsels.

None of the other sumps inspected show evidence of prolonged, ongoing, recent leakage to the extent seen below pool cell 5. However, every sump inspected shows evidence of prior presence of liquid in the liner drain grid outfall pipes.

Moisture evaporates, condenses, and circulates in the enclosed spaces of the sumps. Droplets of water were seen hanging from the relatively clean liner grid outfall pipes below pool cells $9(6.2 .17), 10$, and empty pool cell 
Rev. 0

11 are clear evidence of this. Droplets of water were seen hanging from the ceilings of all sumps, as exemplified in Figure 6.2.29. Temperature gradients within the sump cavities further promote the circulation of water between the sumps, drain gridg, and liners. The pool cell liner temperatures are influenced by the cooling systems and capsules in active pool cells. During winter months, when cooling water temperatures are lower, the pool cell liners are below ambient pool cell area temperatures. Water vapor which evaporates in the pool cell sumps condenses on the undersides of the cooler pool cell liner plates, and drains back to the sumps via the drain grids and outfall pipes. This slow circulation of moisture from the sumps to the drainage grids and back accounts for some of the deposits visible in the drain grid outfall pipes in the absence of liner leakage.

The prevalence of sodium nitrate deposits complicates the search for evidence of leakage. White crystalline deposits observed throughout the sumps systems are attributed to sodium nitrate electrolyte added for testing purposes over the years. Crystalline deposits seen high in the 6-inch leak detector element mounting risers (Figure 6.2.31) show the migration of sodium nitrate over time, despite its low volatility. Sodium nitrate deposits also appear on the lower (Figure 6.2.30) portions of the 6-inch leak detector element mounting risers, above and below the drain grid outfall lines (Figure 6.2 .5 ), on the jet-out pipes (Figure 6.2.32), and even floating on the liquid (Figure 6.2.32).

The deposits seen in Figures 6.2 .1 through 6.2 .32 show that many of the sumps have been flooded above the level of the liner drainage grids. There are no records or institutional memories of prevalent leak detector sump alarms in the active pool cells other than pool cell 5. Therefore the water marks and crystalline deposits are largely or entirely residues from the periodic addition of water and sodium nitrate for leak detector functional testing over the years.

Iiquid levels were measured weekly in each sump opened for video inspection, in order to provide alternative leak detection capability while the detectors were out of service. Figure 3.2.2 presents the sump level readings obtained from these other sumps. The raw data may be found in Tables 6.1.2 through 6.1.4. Each sump jet-out line is one inch above the bottom of the respective sump. The sump levels vary because each sump constitutes a sealed system emptied by a steam jet siphon. Steam jet operation creates a negative pressure in the sump. Any variation in the rate of air in-leakage, initial sump liquid volume, or jet operating parameters will affect how much 
water is drawn into the jet siphon tube, and how much drains back after the jet is shut off. Such variations in the ending sump liquid level after jetting are believed to account for the observed unpredictability in the time intervals between pool cell 5 sump alarm activations.

Sump detectors were only re-installed in pool cell 9, 10, and 11 sumps on May 15, 1996, following the video ingpection. Weekly level measurements continued to be obtained from these sumps in order to confirm the existence of an initially observed upward trend in pool cell 10 sump levels. Level data indicate a 0.12 liter per week water accumulation in the pool cell 10 sump, as shown in Figure 6.4.2. This trend is barely discernible with the current measurement method. Pool cell 10, currently being used for non-radioactive, non-hazardous water collection, does not contain capsules. Any corrective action required in pool cell 10 will be addressed separately from the pool cell 5 issue. 
Figure 3.2.2 Pool Cell 1-12 sump Levels

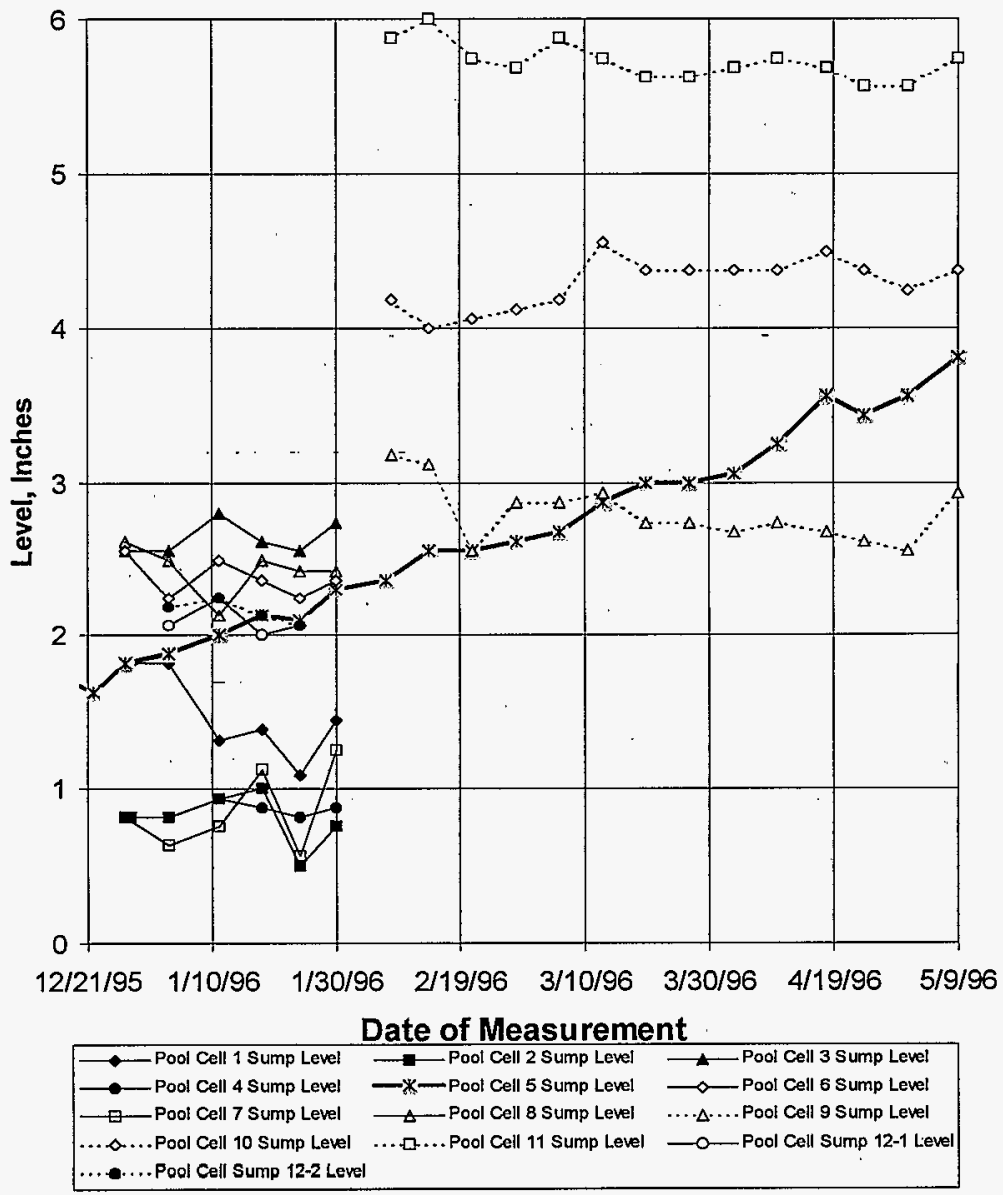


Rev. 0

The potential for significant worsening of the liner leak was considered unlikely due to water chemistry controls in place. While the actual leak location was not found, the very small size, constant rate, and long-term nature of the leak point to an original construction flaw. This cannot be proven, however, since the leak was not found during the leak testing performed during construction. General area corrosion and pitting/crevice corrosion can be ruled out by the good water chemistry controls which have been in place since inception of capsule storage. The water within each pool cell is kept near neutral pH, below 60 degreea $\mathrm{c}$, below $10 \mathrm{ppm}$ chloride, and generally below 4.5 microsiemens/cm conductivity by installed heat exchangers and a demineralizer system (Ref. WHC-SD-WM-SAR-005). The sump sample shows that the water seeping between the liner and the concrete does not absorb enough chloride (only $6.56 \mathrm{ppm}$, within the capsule storage specification) from the concrete to pose much risk of pitting or stress corrosion cracking of the back of the liner, either.

Even if the liner failed altogether, the concrete structure, sump, and risers would contain the water in the short term, and limit the immediate consequences of the event to a loss of 1-2 inches of pool cell water level. This would allow time for recovery actions to relocate the capsules and recover from to the failure.

Contact with demineralized water is known to degrade concrete through leaching of cementitious material. The amount of cementitious material lost from the concrete was estimated from the sample results and leak rate, as shown in Table 3.2.3. A mere cup-full, 0.008 cubic feet, of concrete would account for all the cementitious material detected in the sump sample, if the current leak rate persisted from 1974 to the present. This minor concrete loss corresponds to a cube 2.4 inches on each side, and is of no concern from a structural standpoint. The concrete degradation is distributed along the seepage path from the liner flaw, via the drain grid, to the outfall pipe. The concrete beneath the pool cells is 1.75 feet thick, heavily reinforced, and unaffected by this minor cement 10ss. Therefore, further analysis or testing of the concrete was not considered to be justified.

From the data in Table 3.2.3, it can be projected that 0.1 cubic feet of concrete will potentially be degraded after another 6200 liters of water pass through the liner. This provides a convenient "trigger value" for reevaluating the condition of the concrete if the leak rate worsens. At present leak rates, it will take over 250 years to reach that point. 
Table 3.2.3 Concrete Degradation Estimate

\begin{tabular}{|c|c|c|c|}
\hline Species & $\begin{array}{c}\text { Pool Cell } 5 \text { sump } \\
\text { Sample R7009, mg/L }\end{array}$ & $\begin{array}{l}\text { Portland cement } \\
\text { component, } \mathrm{mg} / \mathrm{L}\end{array}$ & $\begin{array}{c}\text { Portland cement } \\
\text { component }\end{array}$ \\
\hline $\mathrm{pH}$ & 8.38 & $\mathrm{~N} / \mathrm{A}$ & \\
\hline $\mathrm{Al}$ & 0.83 & 3.15 & Al203 \\
\hline B & 0.21 & 1.36 & B203 \\
\hline $\mathrm{Ca}$ & 3.44 & 4.88 & $\mathrm{CaO}$ \\
\hline $\mathrm{Cr}$ & 0.02 & 0.0461 & CrO3 \\
\hline $\mathrm{Na}$ & 363.00 & $\mathrm{~N} / \mathrm{A}$ & \\
\hline $\mathrm{Ba}$ & $<0.05$ & $\mathrm{~N} / \mathrm{A}$ & \\
\hline $\mathrm{Mg}$ & $<0.10$ & $\mathrm{~N} / \mathrm{A}$ & \\
\hline $\mathrm{K}$ & 16.00 & 38.5 & $\mathrm{~K} 2 \mathrm{O}$ \\
\hline $\mathrm{Si}$ & 5.22 & 11.2 & SiO2 \\
\hline $\mathrm{Cl}$ & 6.56 & 10.8 & $\mathrm{NaCl}$ \\
\hline NO3 & 979.00 & $\mathrm{~N} / \mathrm{A}$ & \\
\hline $\mathrm{SO} 4$ & $<0.746$ & $\mathrm{~N} / \mathrm{A}$ & \\
\hline $\begin{array}{l}\text { Total Portlar } \\
\text { Concentratior }\end{array}$ & $\begin{array}{l}\text { Cement Constituent } \\
\mathrm{mg} / \mathrm{L}\end{array}$ & 69.96 & . \\
\hline
\end{tabular}

\begin{tabular}{|c|c|}
\hline Leak rate, L/ week: & 0.47 \\
\hline Weeks since 1974: & 1148 \\
\hline Total liters leaked since 1974: & 545 \\
\hline $\begin{array}{l}\text { Grams of detected Portland } \\
\text { cement constituents } \\
\text { (Total liters x concentration) }\end{array}$ & 38 \\
\hline $\begin{array}{l}\text { Weight of bag of Portland cement, } \\
\text { lb (Ref. Dunham, Clarence W., "The } \\
\text { Theory and Practice of Reinforced } \\
\text { Concrete," McGraw-Hill, } 1966 .\end{array}$ & 94 \\
\hline $\begin{array}{l}\text { Bags cement per yard of concrete } \\
\text { ( } 5 \text { typical, } 3 \text { VERY conservative) }\end{array}$ & 3 \\
\hline lb Portland Cement/ Yard concrete & 282 \\
\hline $\begin{array}{l}\text { Yards concrete corresponding to } \\
\text { detected Portland cement: }\end{array}$ & 0.000298 \\
\hline Cubic feet concrete: & 0.008 \\
\hline CC concrete: & 228 \\
\hline
\end{tabular}




\subsection{Actions Taken to Ensure Continued Safe Capsule Storage}

The actions taken to ensure continued safe capsule storage include regular monitoring of the leak rate, and putting contingency capsule relocation plans in place in the event of an unanticipated worsening of the leak rate. Ag discussed in the previous section, the very small magnitude of the leak rate, the lack of structural degradation, and the limited immediate consequences of even a total liner failure pose little risk to continued safe storage of capsules in pool cell 5. Present conditions do not warrant more costly and drastic measures such as relocating capsules, draining the pool, performing nondestructive examination, or repairing the liner. Such actions may be reconsidered if the leak worsens in the future. Capsules will continue to be safely stored in pool cell 5 .

Regular monitoring of the leak rate has been ongoing since the leak was discovered. As described in the previous section, trending of the leak rate and tracking the total quantity of demineralized water passing through the liner is important to ensure the structural integrity of the concrete. This activity is currently being performed manually. Design of an improved sump level monitoring system has been initiated. This system will be described more fully in section 5, which defines the follow-on actions required to respond to the pool cell 5 liner leak.

Alternate capsule storage options in the event of significant worsening of the liner leak were considered. As shown in Table 3.3.1, there is sufficient space and heat transfer capacity (ref. OSD-B-257-00055, part ii) in the active storage pools to contain all the capsules now stored in pool cell 5. If pool cell 5 must be drained for examination or repair, pool celis 4 and 6 must also be emptied of capsules and remain filled with water in order to provide shielding from the capsules in pool cells 3 and 7 . This consideration makes pool cell 1 the preferred destination for the capsules in pool cell 5 . As shown in the last column of Table 3.3.1, the capsules from pool cell 5 would not need to be moved a second time. The capsules in pool cell 6 could be added to those already in pool cell 3, and the capsules in pool cell 4 could be added to those from pool cell 5 in pool cell 1. 
Table 3.3.1 Alternate Capsule storage Options

\begin{tabular}{|c|c|c|c|c|c|c|}
\hline \multicolumn{2}{|l|}{ Existing Arrangement } & \multicolumn{3}{l|}{$\begin{array}{l}\text { Move capsules from pool } \\
\text { cell 5emove capsules from }\end{array}$} \\
\hline Pool & $\begin{array}{c}\text { Capsules } \\
\text { Limit } \\
663\end{array}$ & $\begin{array}{c}\text { Watts } \\
\text { Limit } \\
249048\end{array}$ & $\begin{array}{c}\text { Capsules } \\
\text { Limit } \\
663\end{array}$ & $\begin{array}{c}\text { Watts } \\
\text { Limit } \\
249048\end{array}$ & $\begin{array}{c}\text { Capsules } \\
\text { Iimit } \\
663\end{array}$ & $\begin{array}{c}\text { Watts } \\
\text { Limit } \\
249048\end{array}$ \\
\hline 1 & 0 & 0 & 274 & 62347 & 647 & 140644 \\
\hline 3 & 331 & 80164 & 331 & 80164 & 632 & 140120 \\
\hline 4 & 301 & 59956 & 301 & 59956 & 0 & 0 \\
\hline 5 & 274 & 62347 & 0 & 0 & 0 & 0 \\
\hline 6 & 373 & 78297 & 373 & 78297 & 0 & 0 \\
\hline 7 & 596 & 111694 & 596 & 111694 & 596 & 111694 \\
\hline total & 1875 & 392458 & 1875 & 392458 & 1875 & 392458 \\
\hline
\end{tabular}

A plan for relocating capsules from pool cell 5 to pool cell 1 in the event of a gerious liner leak was developed (memo 16550-95-105, I. I. Nunn to J. I. Pennock, "Recovery Actions for Leaking pool cel1," November 21, 1995 ). Recovery actions would be triggered by a pool cell liquid level decrease of 4 . inches or more in 4 hours, or by a decreasing pool cell liquid level while adding demineralized water via the installed water addition system. Capsules would then be relocated from the failed pool cell to pool cell 1 . Procedure E0-906-003, "Transfer and storage of Capsules," is already in place. Recommended changes have been made to procedures EO-001-006, "Emergency Reaponge in Pool Cells," and EO-040-001, "Pool Cell surveillance," to implement the capsule relocation plan. Additional pool cell tongs were fabricated to ensure that capsules can be rapidly relocated if needed. A total of six pool cell tongs are now on hand as recommended: Two full-length tongs for movement of capaules from the pool cell 5 storage racks to the transfer port, two short tongs to move capsules along the transfer aisle to pool cell 1 , and two full-length tongs to move capsules from the transfer port to their temporary pool cell 1 storage locations. A mobile catwalk platform was installed to resolve ergonomic concerng with large-scale movement of capsules. 


\subsection{CURRENT STATUS}

Th1s section presents the current status of pool cell 5 , as well as the current status of action items identified in the subject occurrence Report and Plant Review Committee meeting minutes.

\subsection{Status of Pool Cell 5}

Pool cell 5 remains in service as an active capsule storage pool. The pool cell 5 sump leak detector is out of service to allow for manual sump level measurements. Periodic manual monitoring of the pool cell 5 leak detector sump level is ongoing until improved sump ingtrumentation is in place. The leak rate remains very low, only 0.47 liters per week. Contingency plans, procedures, and equipment are in place to relocate the capsules if an unanticipated deterioration of the liner occurs.

\subsection{Status of Occurrence Report Actions}

The plant committed to several actions in the related occurrence Report (ref. RL-WHC-BPLANT-1995-0037). The current status of these actions is as follows:

1. Document pool cell \#5 leak rate: Completed by issuance of thi.e document.

2. Obtain water sample from pool cell and use sample analysis to compare possible sources: complete. See Table 3.1.1.

3. Perform a video surveillance of the leak detector sump: complete. see Figures 6.2 .1 and 6.2 .2 .

4. Based on the results of actions $\# 2$ and $\# 3$, develop any corrective actions to identify the leak source and respond to the discovery: complete. see section 5 of this report.

5. Continue to monitor rate of level increase in the sump: Ongoing. Leak rate remains constant. Manual monitoring will continue until permanent sump monitoring instrumentation is installed.

6. Perform an evaluation of alternate storage options for the cesium and strontium capsules in pool cell 5: complete. See section 3.3 of this report. 


\subsection{Status of Actions Identified in Plant Review Committee Meeting}

The plant committed to actions when the Plant Review Committee (PRC) reviewed the USQ screening for the referenced occurence. The current status of these actions (ref. L. I. Covey, "Meeting Minutes, PRC Meeting- Pool Cell 5 Liner Leak") is as follows:

2. Conduct and document interviews with operators which substantiate this leak as existing for the past 20 years: complete. See Appendix 6.3 of this report.

2. Obtain videos of the other pool cell sumps to determine if there are leaks in the other sumps: complete. See Figures 6.2 .3 through 6.2 .32

3. Obtain sump levels weekly: ongoing until modified detector installed.

4. Develop a procedure for emergency movement of capsules from pool cell 5: complete, See aection 3.3 of this report. 


\subsection{FOLLOW-ON ACTIONS}

The pool cell 5 leak detector will be modified to provide a level measurement capability in addition to the alarm function, and re-installed in the sump. Until then, weekly manual measurements will continue to monitor the leak rate. Operating and maintenance documentation will be revised accordingly. The estimated completion date for this upgrade is July 31 , 1996.

The structural integrity of the pool cell will be re-evaluated if the leak rate increases sufficiently to raise the possibility of 0.1 cubic feet of concrete being degraded. This corresponds to at total of 62001 iters of demineralized water passing through the liner in addition to that which has leaked to date. At current leak rates, it will take over 250 years to reach this cumulative leak volume.

The capsules now stored in pool cell 5 will remain there unless conditions change to warrant their movement to pool cell 1 . 


\subsection{APPENDIX}

\subsection{Sump Level Measurements}

Pool cell 5 levels have been measured and trended since June 27, 1995. Table depicts the pool cell 5 sump level data obtained through April $18,1996$. Two external disturbances affected the sump levels during september, 1995. small sump level decrease resulted from sampling the sump on september 1 , 1995. The 0.25-inch level reading on september 18, 1995 resulted when the sump was pumped out via tubing inserted in the leak detector riser, in order to provide access for the video inspection. The raw data are shown in Table 6.1 .1 , below.

Table 6.1.1 Pool Cell 5 sump Levels, Inches

\begin{tabular}{|c|c|c|c|c|c|c|c|c|c|}
\hline & \multicolumn{2}{|c|}{ WESE } & \multicolumn{2}{|c|}{ Pool Cell 5 Sump } & \multicolumn{3}{|c|}{ Level Measurements } & & \\
\hline Date & & ev & 1 , In. & Date & & evel, In. & Date & Le & In. \\
\hline $6 / 27 / 95$ & 5 & - & $1 / 4$ & $12 / 1 / 95$ & 1 & $1 / 2$ & $3 / 6 / 96$ & 2 & $11 / 16$ \\
\hline $7 / 27 / 95$ & 5 & - & $1 / 2$ & $12 / 7 / 95$ & 1 & $1 / 2$ & $3 / 13 / 96$ & $2-$ & $7 / 8$ \\
\hline $8 / 10 / 95$ & 5 & - & $3 / 4$ & $12 / 13 / 95$ & 1 & $-13 / 16$ & $3 / 20 / 96$ & & 3 \\
\hline $8 / 17 / 95$ & 6 & - & $1 / 8$ & $12 / 22 / 95$ & 1 & $5 / 8$ & $3 / 27 / 96$ & & 3 \\
\hline $9 / 1 / 95$ & 7 & - & $1 / 4$ & $12 / 27 / 95$ & 1 & $-13 / 16$ & $4 / 3 / 96$ & $3-$ & $1 / 16$ \\
\hline $9 / 8 / 95$ & 6 & - & $5 / 8$ & $1 / 3 / 96$ & 1 & $7 / 8$ & $4 / 10 / 96$ & $3-$ & $1 / 4$ \\
\hline $9 / 18 / 95$ & 0 & - & $1 / 4$ & $1 / 11 / 96$ & & 2 & $4 / 18 / 96$ & 3 & $9 / 16$ \\
\hline $9 / 21 / 95$ & 0 & - & $5 / 8$ & $1 / 18 / 96$ & 2 & $1 / 8$ & $4 / 10 / 96$ & $3-$ & $1 / 4$ \\
\hline $9 / 29 / 95$ & 0 & - & $3 / 4$ & $1 / 24 / 96$ & 2 & $3 / 32$ & $5 / 1 / 96$ & $3-$ & $9 / 16$ \\
\hline $10 / 12 / 95$ & 0 & - & $13 / 16$ & $1 / 30 / 96$ & 2 & $5 / 16$ & $5 / 9 / 96$ & $3-$ & $13 / 16$ \\
\hline $10 / 19 / 95$ & 0 & - & $7 / 8$ & $2 / 7 / 96$ & 2 & $3 / 8$ & $5 / 16 / 96$ & $3-$ & $7 / 8$ \\
\hline $11 / 3 / 95$ & 1 & - & $1 / 4$ & $2 / 14 / 96$ & 2 & $9 / 16$ & $5 / 24 / 96$ & & 4 \\
\hline $11 / 10 / 95$ & 1 & - & $15 / 79$ & $2 / 21 / 96$ & 2 & $9 / 16$ & & & \\
\hline $11 / 17 / 95$ & 1 & - & $9 / 29$ & $2 / 28 / 96$ & 2 & $5 / 8$ & & & \\
\hline
\end{tabular}

Whenever a sump detector was removed for inspection, that manual level measurements of that sump were obtained weekly to provide alternative leak detection capability. The raw sump level data are tabulated in Tables 6.1.2, 6.1.3, and 6.1.4, below. The data are grouped and pregented in the order given by the timing of the video inspections. Access was gained for level. measurement only while leak detectors were removed for video inspections. None 
of the other active capsule storage pool sumps has a consistent pattern of level increaseg similar to that seen in the pool cell 5 aump. The sump associated with pool cell 10, which is used as a foul water collection basin, initially displayed a possible upward sump level trend. A linear leastsquares interpolation of the pool cell 10 data indicates a water accumulation rate of 0.12 liters per week, about one-fourth of that observed for pool cell 5. The pool cell 10 sump alarm activated during January, 1996, before the detector was removed for inspection. Weekly readings continued until May 9 , 1996, when it was concluded that no sustained trend existed. The detector was re-installed on May 15, 1996.

Table 6.1.2 Pool Cell 1 And 2 Sump Levels, Inches

\begin{tabular}{|c|c|c|}
\hline Date & $\begin{array}{c}\text { Pool Cell 1 } \\
\text { Sump }\end{array}$ & $\begin{array}{c}\text { Pool Cell 2 } \\
\text { Sump }\end{array}$ \\
\hline $12 / 28 / 95$ & $1-13 / 16$ & $0-13 / 16$ \\
\hline $1 / 3 / 96$ & $1-13 / 16$ & $0-13 / 16$ \\
\hline $1 / 11 / 96$ & $1-5 / 16$ & $0-15 / 16$ \\
\hline $1 / 18 / 96$ & $1-3 / 8$ & 1 \\
\hline $1 / 24 / 96$ & $1-3 / 32$ & $0-1 / 2$ \\
\hline $1 / 30 / 96$ & $1-7 / 16$ & $0-$ \\
\hline
\end{tabular}

Table 6.1.3 Pool cell 3-4, 6-8, and 12 sump Levels, Inches

\begin{tabular}{|c|c|c|c|c|c|c|c|c|c|c|c|c|c|c|}
\hline Date & \multicolumn{2}{|c|}{$\begin{array}{c}\text { Pool Cell } 3 \\
\text { sump }\end{array}$} & \multicolumn{2}{|c|}{$\begin{array}{c}\text { Pool Cell } 4 \\
\text { Sump }\end{array}$} & \multicolumn{2}{|c|}{$\begin{array}{c}\text { Pool Cell } 6 \\
\text { sump }\end{array}$} & \multicolumn{2}{|c|}{$\begin{array}{c}\text { Pool cell } 7 \\
\text { Sunp }\end{array}$} & \multicolumn{2}{|c|}{$\begin{array}{c}\text { Pool Cell } 8 \\
\text { Sump }\end{array}$} & \multicolumn{2}{|c|}{$\begin{array}{r}\text { Pool Cell } 12 \\
\text { Sump } 1\end{array}$} & \multicolumn{2}{|c|}{$\begin{array}{c}\text { Pool Cell } 12 \\
\text { Surmp } 2\end{array}$} \\
\hline $12 / 27 / 95$ & 2 & $9 / 16$ & $0-$ & $13 / 16$ & $2-$ & $9 / 16$ & 0 & $13 / 16$ & $2-$ & $5 / 8$ & & $\mathrm{~J} / \mathrm{A}$ & & $1 / \mathrm{A}$ \\
\hline $1 / 3 / 96$ & 2 & $9 / 16$ & $0-$ & $13 / 16$ & $2-$ & $1 / 4$ & $0-$ & $5 / 8$ & $2-$ & $1 / 2$ & $2-$ & $1 / 16$ & & $3 / 16$ \\
\hline $1 / 11 / 96$ & 2 & $13 / 16$ & $0-$ & $15 / 16$ & $2-$ & $1 / 2$ & 0 & $3 / 4$ & $2-$ & $1 / 8$ & $2-$ & $1 / 4$ & $2-$ & $1 / 4$ \\
\hline $1 / 18 / 96$ & 2 & $5 / 8$ & $0-$ & $7 / 8$ & $2-$ & $3 / 8$ & $1-$ & $1 / 8$ & $2-$ & $1 / 2$ & & 2 & $2-$ & $1 / 8$ \\
\hline $1 / 24 / 96$ & 2 & $9 / 16$ & $0-$ & $13 / 16$ & $2-$ & $1 / 4$ & 0 & $9 / 16$ & $2-$ & $7 / 16$ & 2 & $1 / 1$ & $2-$ & $1 / 16$ \\
\hline $1 / 30 / 96$ & 2 & $3 / 4$ & $0-$ & $7 / 8$ & $2-$ & $3 / 8$ & $1-$ & $1 / 4$ & $2-$ & $7 / 16$ & & $\mathrm{~J} / \mathrm{A}$ & & $/ / A$ \\
\hline
\end{tabular}


Table 6.1.4 Pool Cell 9-11 Sump Levels, Inches

\begin{tabular}{|c|c|c|c|c|c|c|c|c|c|}
\hline Date & \multicolumn{3}{|c|}{ Pool Cell 9} & \multicolumn{3}{|c|}{ Pool Cell 10} & \multicolumn{3}{|c|}{ Pool Cell 11} \\
\hline $2 / 8 / 96$ & 3 & - & $3 / 16$ & 4 & - & $3 / 16$ & 5 & - & $7 / 8$ \\
\hline $2 / 14 / 96$ & 3 & - & $1 / 8$ & \multicolumn{3}{|c|}{4} & \multicolumn{3}{|r|}{6} \\
\hline $2 / 21 / 96$ & 2 & - & $9 / 16$ & 4 & - & $1 / 16$ & 5 & - & $3 / 4$ \\
\hline $2 / 28 / 96$ & 2 & - & $7 / 8$ & 4 & - & $1 / 8$ & 5 & - & $11 / 16$ \\
\hline $3 / 6 / 96$ & 2 & - & $7 / 8$ & 4 & - & $3 / 16$ & 5 & - & $7 / 8$ \\
\hline $3 / 13 / 96$ & 2 & - & $15 / 16$ & 4 & - & $9 / 16$ & 5 & - & $3 / 4$ \\
\hline $3 / 20 / 96$ & 2 & - & $3 / 4$ & 4 & - & $3 / 8$ & 5 & - & $5 / 8$ \\
\hline $3 / 27 / 96$ & 2 & - & $3 / 4$ & 4 & - & $3 / 8$ & 5 & - & $5 / 8$ \\
\hline $4 / 3 / 96$ & 2 & - & $11 / 16$ & 4 & - & $3 / 8$ & 5 & - & $11 / 16$ \\
\hline $4 / 10 / 96$ & 2 & - & $3 / 4$ & 4 & - & $3 / 8$ & 5 & - & $3 / 4$ \\
\hline $4 / 18 / 96$ & 2 & - & $11 / 16$ & 4 & - & $1 / 2$ & 5 & - & $11 / 16$ \\
\hline $4 / 24 / 96$ & 2 & - & $5 / 8$ & 4 & - & $3 / 8$ & 5 & - & $9 / 16$ \\
\hline $5 / 1 / 96$ & 2 & - & $9 / 16$ & 4 & - & $1 / 4$ & 5 & - & $9 / 16$ \\
\hline $5 / 9 / 96$ & 2 & - & $15 / 16$ & 4 & - & $3 / 8$ & 5 & - & $3 / 4$ \\
\hline
\end{tabular}


Rev. 0

\subsection{Sump Video Inspection Results}

Video inspections of the pool cell sumps are recorded on videotapes \#2001465, 200-1466, 200-1467, and 200-1468 archived by the whc surveillance Systems Integration organization. Figure 6.2.1 shows the outfall of the 1inch pipe which routes the pool cell 5 liner drainage grid into the side of the 20-inch sump. Deposits in and extending downward from the 1-inch pipe show that a slow leak has existed in pool cell 5 for a considerable length of time. Figure 6.2.2 shows the white-colored deposit on the bottom of the 1inch outfall pipe in greater detail.

For comparison, Figures 6.2.3, through 6.2.32 show the condition of sumps beneath pool cells $1,2,3,4,6,7,8,9,10,11$, and 12, including both of the sumps servicing the transfer aisle (pool cell 12). Except for sump 12-2, these sumps are similar in construction to the pool cell 5 sump. Sump 12-2 is similax to the others except that it collects water from two separate drainage grids. The left-hand pipe in Figure 6.2 .25 is the outfall from the drainage grid beneath the southern portion of the transfer aisle. The right-hand pipe in Figure 6.2.25 is the outfall from the drain grid under the cask pit.

None of the other sumps inspected show evidence of prolonged, ongoing, recent leakage to the extent seen below pool cell 5. However, every sump inspected shows evidence of prior presence of liquid in the liner drain grid outfall pipes.

Moisture evaporates, condenses, and circulates in the enclosed spaces of the sumps. Droplets of water were seen hanging from the relatively clean liner grid outfall pipes below pool cells $9(6.2 .17), 10$, and empty pool cell 11 are clear evidence of this. Droplets of water were seen hanging from the ceilings of all sumps, as exemplified in Figure 6.2.29. Temperature gradients within the sump cavities further promote the circulation of water between the sumps, drain grids, and liners. The pool cell liner temperatures are influenced by the cooling systems and capsules in active pool cella. During winter months, when cooling water temperatures are lower, the pool cell liners are below ambient pool cell area temperatures. Water vapor which evaporates in the pool cell sumps condenses on the undersides of the cooler pool cell liner plates, and drains back to the sumps via the drain grids and outfall pipes. This slow circulation of moisture from the sumps to the drainage grids and back accounts for some of the deposits visible in the drain grid outfall pipes in the absence of liner leakage. 
The prevalence of sodium nitrate deposits complicates the search for evidence of leakage. White crystalline deposits observed throughout the sumps systems are attributed to sodium nitrate electrolyte added for testing purposeg over the years. Crystalline deposits seen high in the 6-inch leak detector element mounting risers (Figure 6.2.31) show the migration of sodium nitrate over time, despite its low volatility. Sodium nitrate deposits also appear on the lower (Figure 6.2.30) portions of the 6-inch leak detector element mounting risers, above and below the drain grid outfall lines (Figure 6.2.5), on the jet-out pipes (Figure 6.2.32), and even floating on the 1 iquid (Figure 6.2.32).

The deposits seen in Figures 6.2 .1 through 6.2 .32 show that many of the sumps have been flooded above the level of the liner drainage grids. There are no records or institutional memories of prevalent leak detector sump alarms in the active pool cells other than pool cell 5 . Therefore the water marks and crystalline depogits are, at least part, residues from the periodic addition of water and sodium nitrate for leak detector functional testing over the years. 
Rev. 0

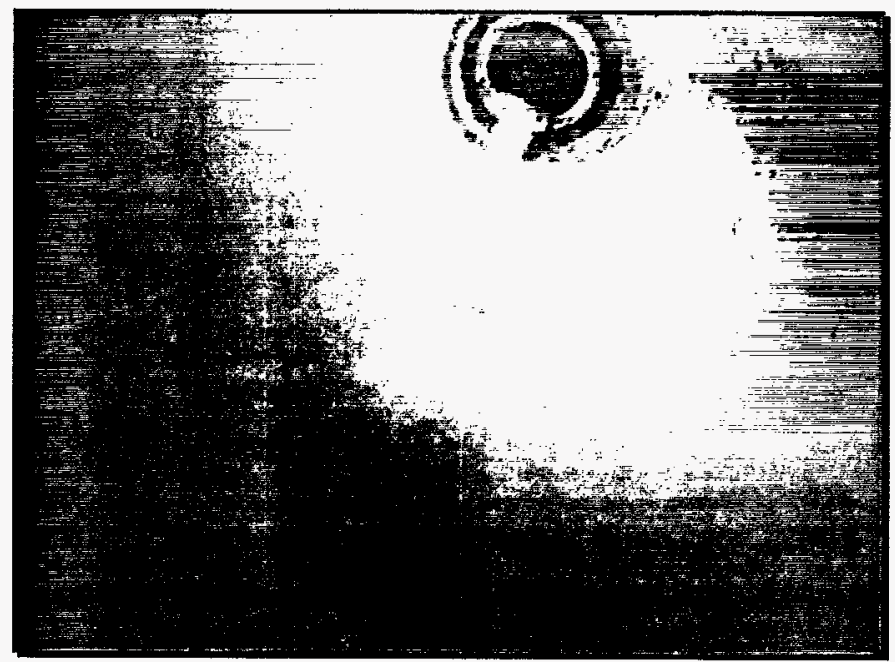

FIGURE 6.2.1 WESF Pool Cell 5 Sump Overall View

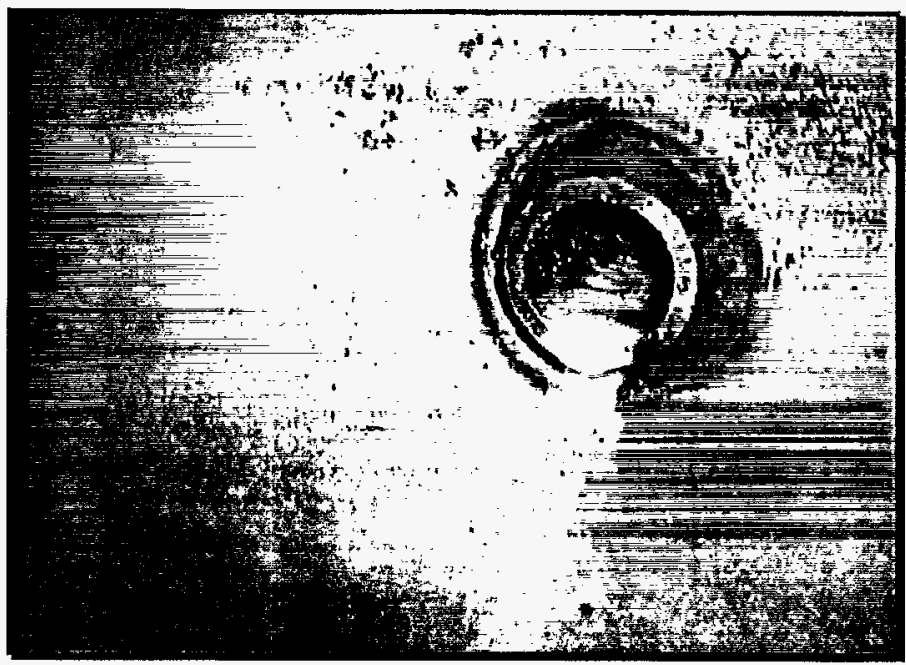

FIGURE 6.2.2 WESF Pool Cell 5 Liner Drain Grid Outfall Pipe 
Rev. 0

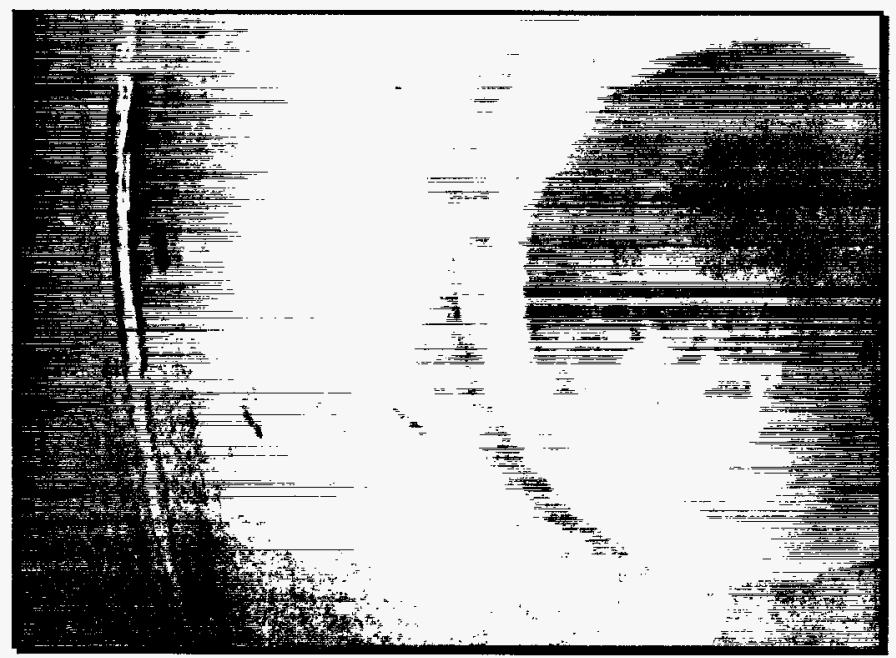

FIGURE 6.2.3 WESF Pool Cell 1 Liner Drain Grid Outfall Pipe

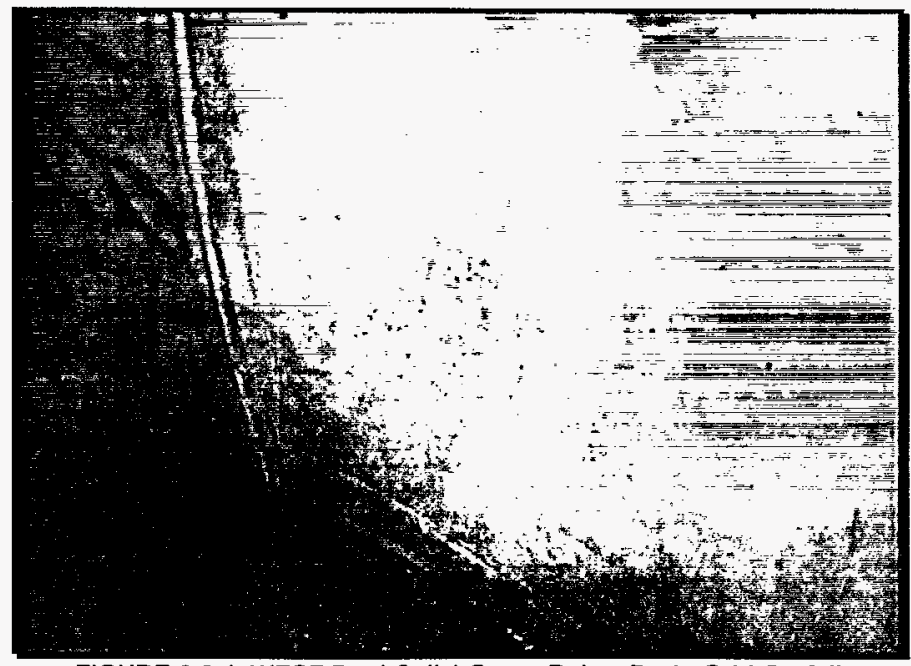

FIGURE 6.2.4 WESF Pool Cell 1 Sump Below Drain Grid Outfall 
Rev. 0

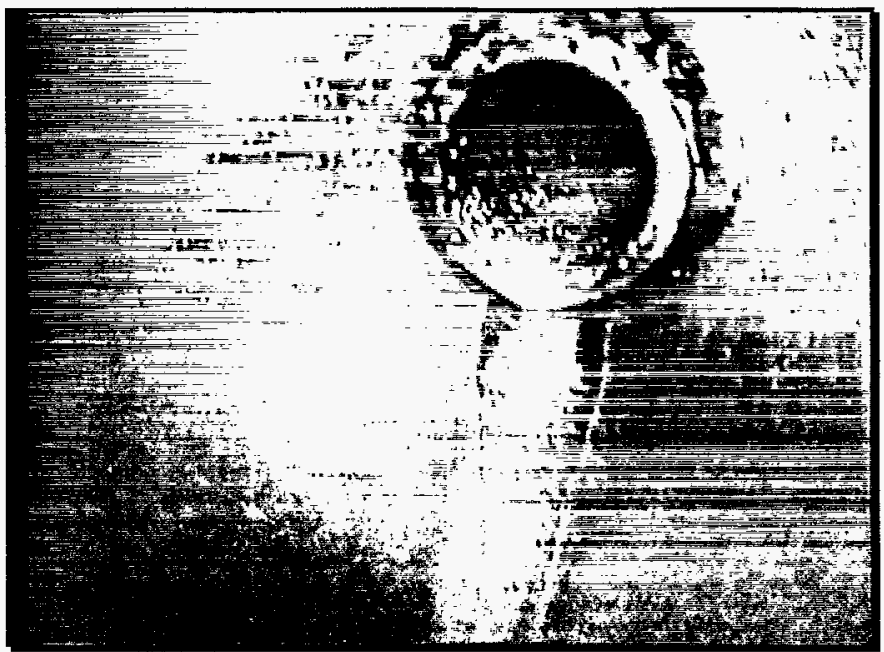

FIGURE 6.2.5 WESF Pool Cell 2 Liner Drain Grid Outfall Pipe

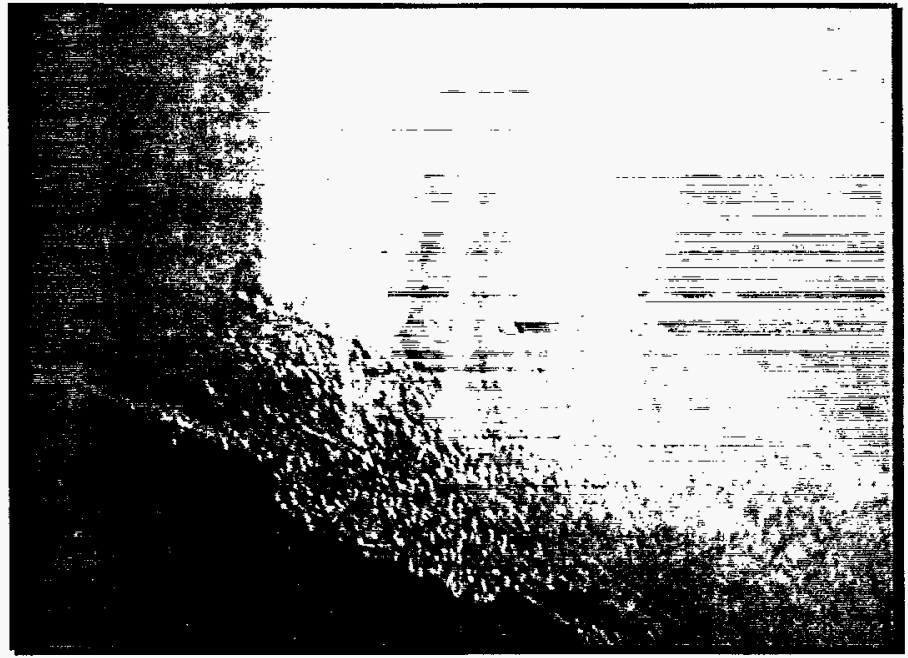

FIGURE 6.2.6 WESF Pool Cell 2 Sump Below Drain Grid Outfall 
Rev, 0

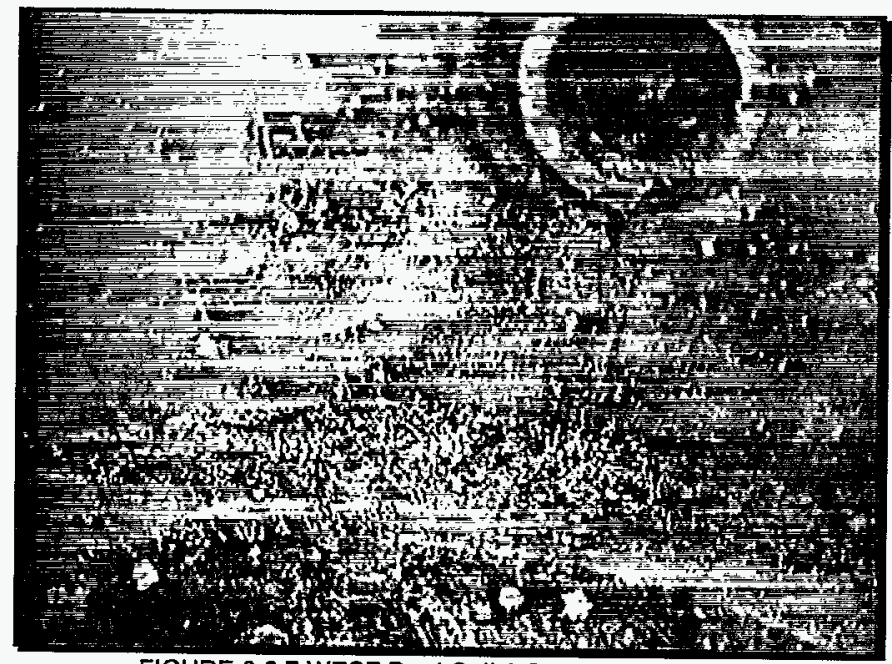

FIGURE 6.2.7 WESF Pool Cell 3 Sump Overall View

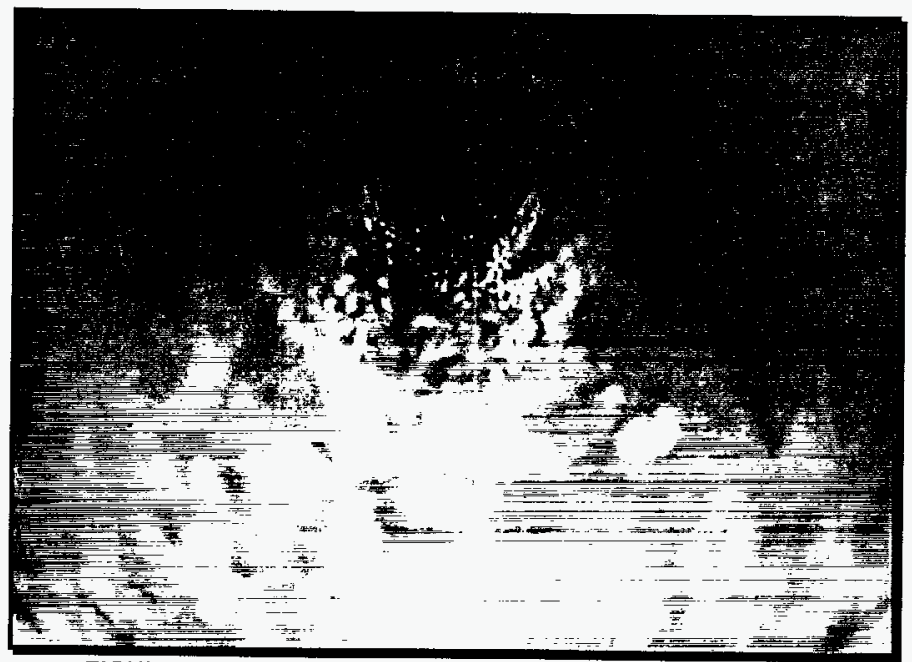

FIGURE 6.2.8 WESF Pool Cell 3 Liner Drain Grid Outfall Pipe 


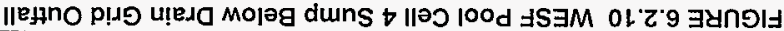

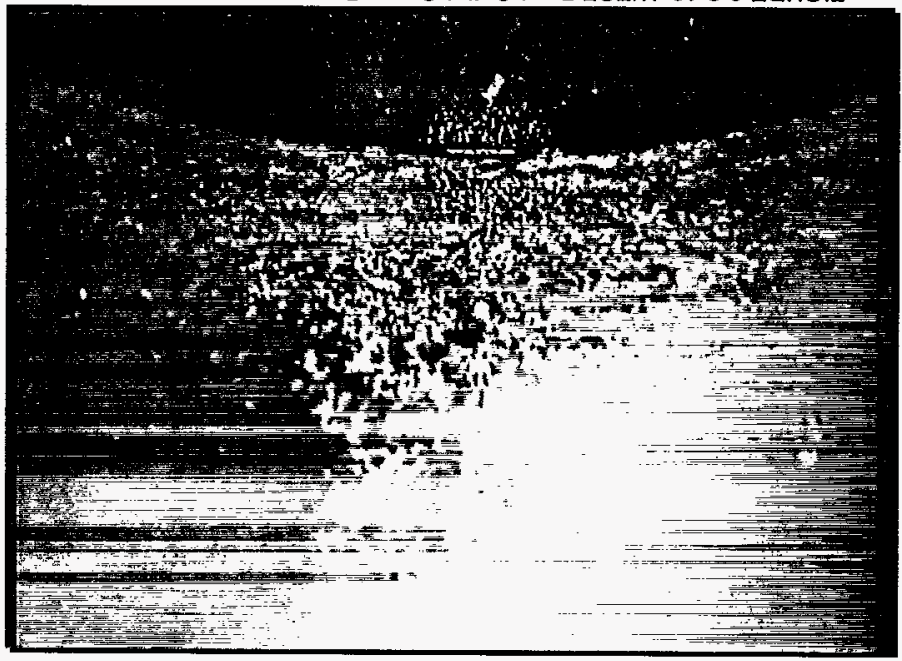

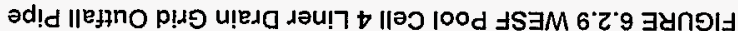

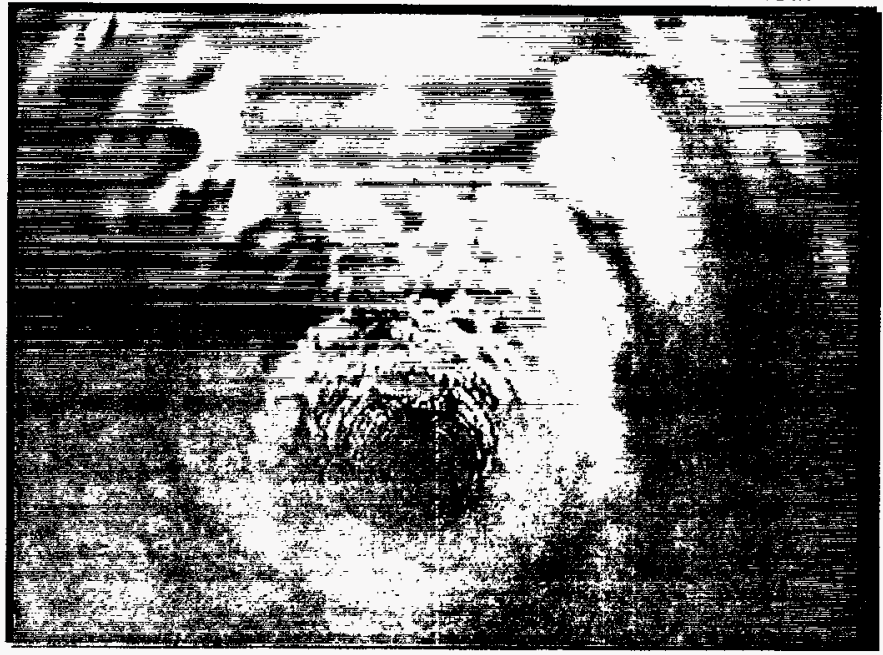

0 мәу

$S \triangleright L-1 \perp-W M-a S-O H M$ 


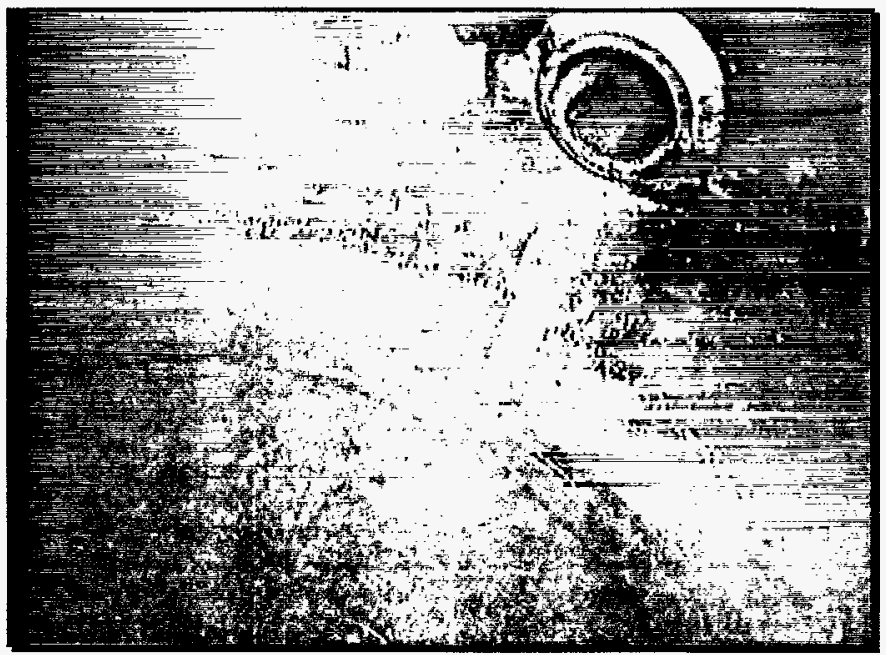

FIGURE 6.2.11 WESF Pool Cell 6 SUmp Overall View

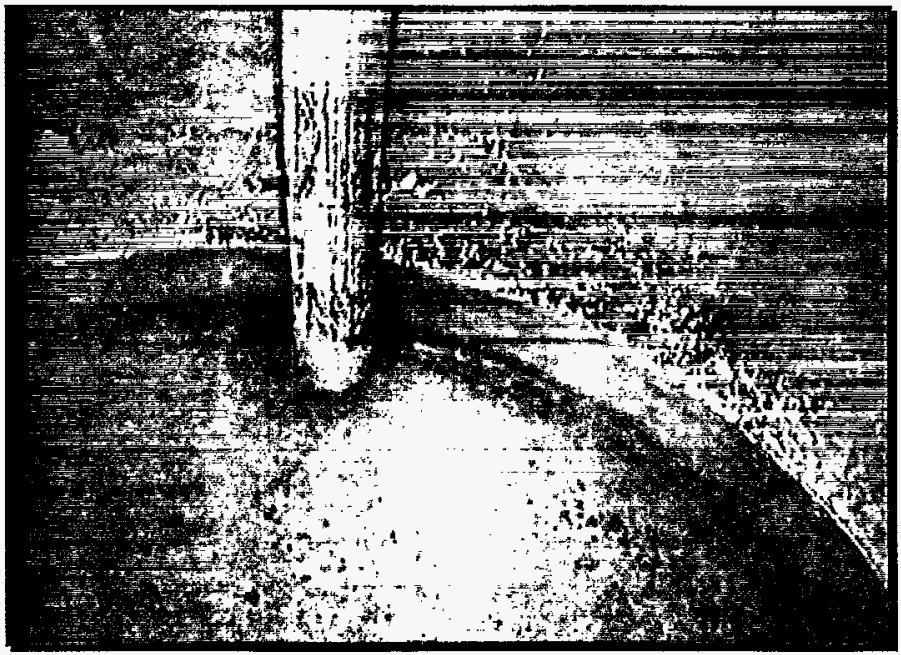

FIGURE 6.2.12 WESF Pool Cell 6 Sump Jet Out Pipe 
Rev. 0

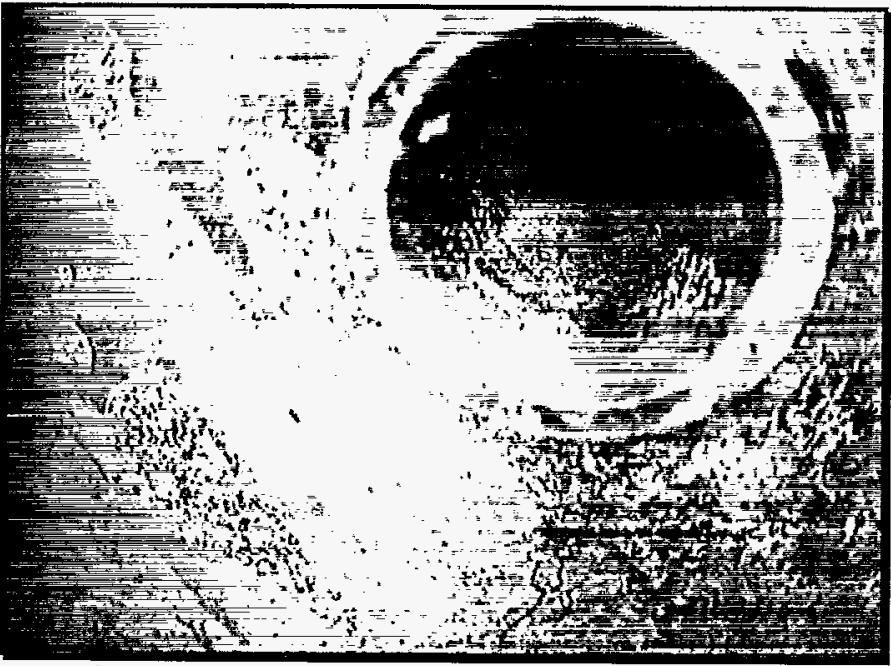

FIGURE 6.2.13 WESF Pool Cell 7 Liner Drain Grid Outfall Pipe

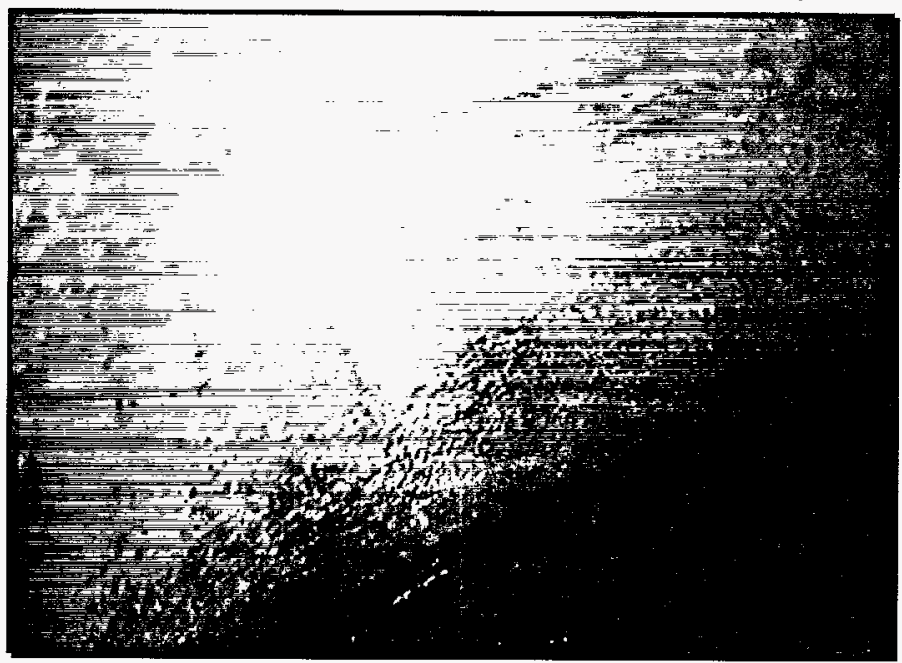

FIGURE 6.2.14 WESF Pool Cell 7 Sump Below Drain Grid Outfall 


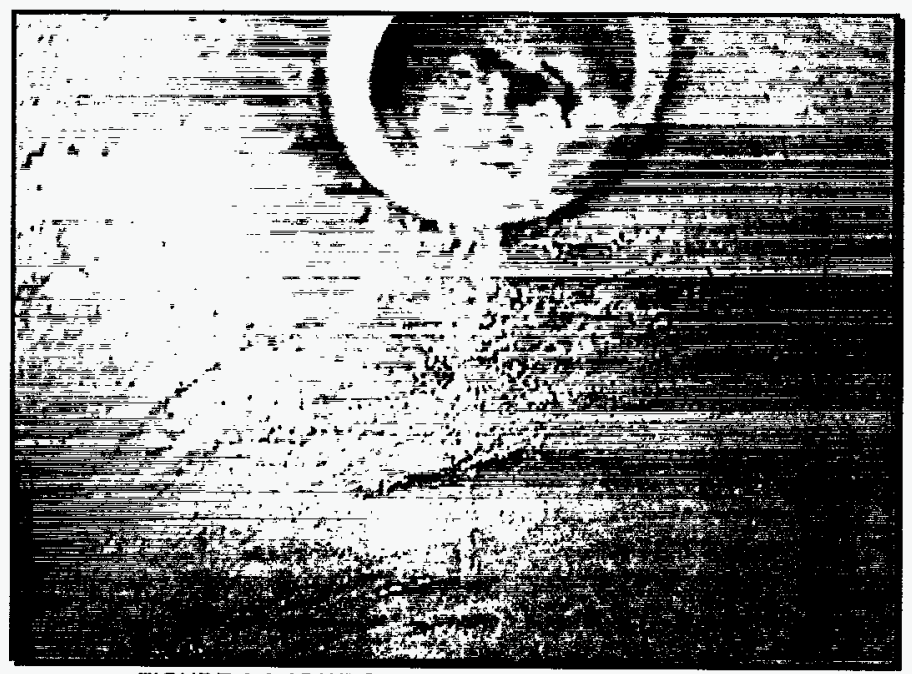

FIGURE 6.2.15 WESF Pool Cell 8 Sump Overall View

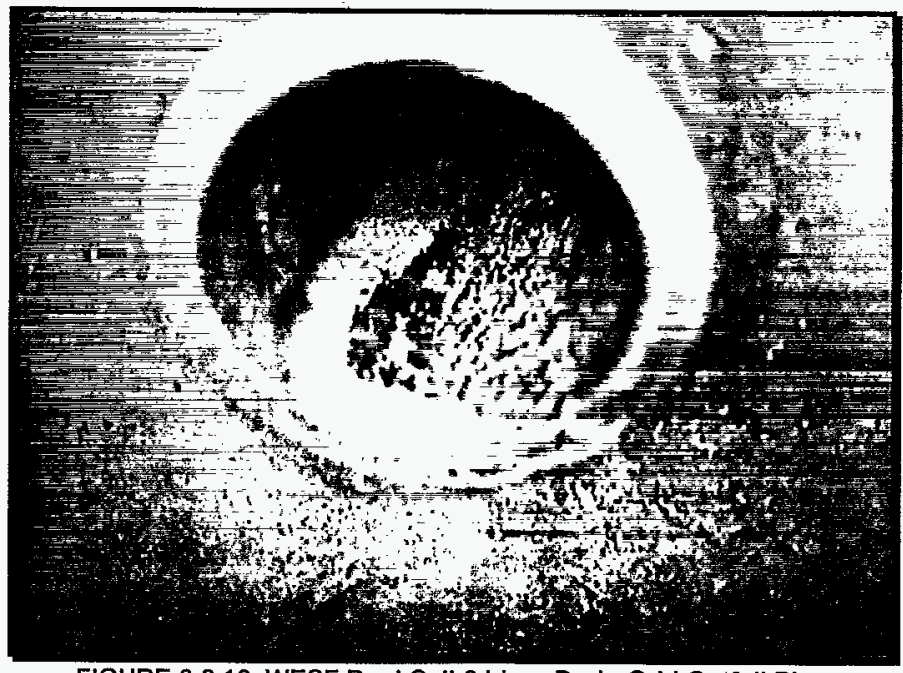

FIGURE 6.2.16 WESF Pool Cell 8 Liner Drain Grid Outfall Pipe 
Rev, 0

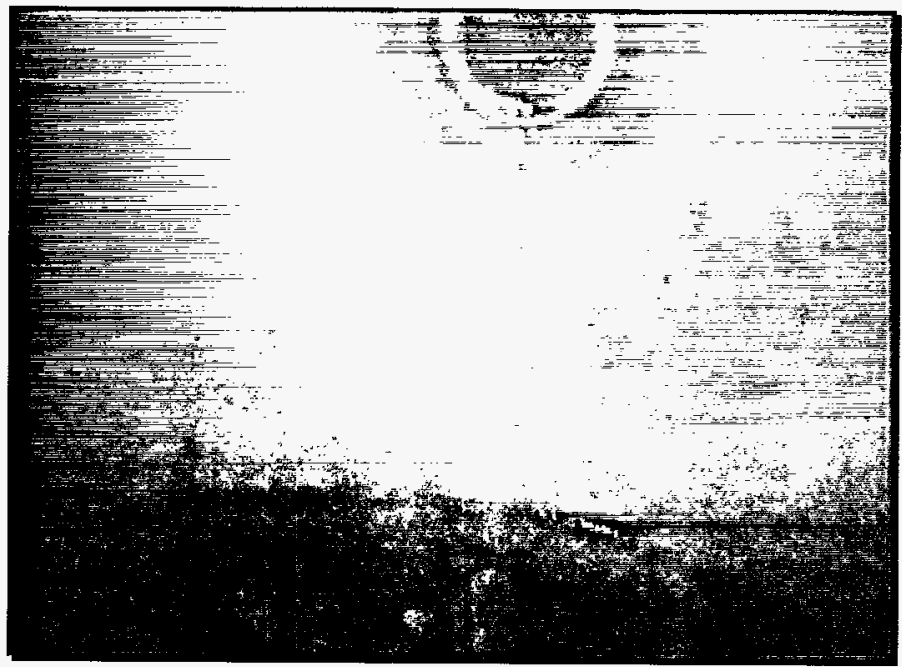

FIGURE 6.2.17 WESF Pool Cell 9 Sump Overall View

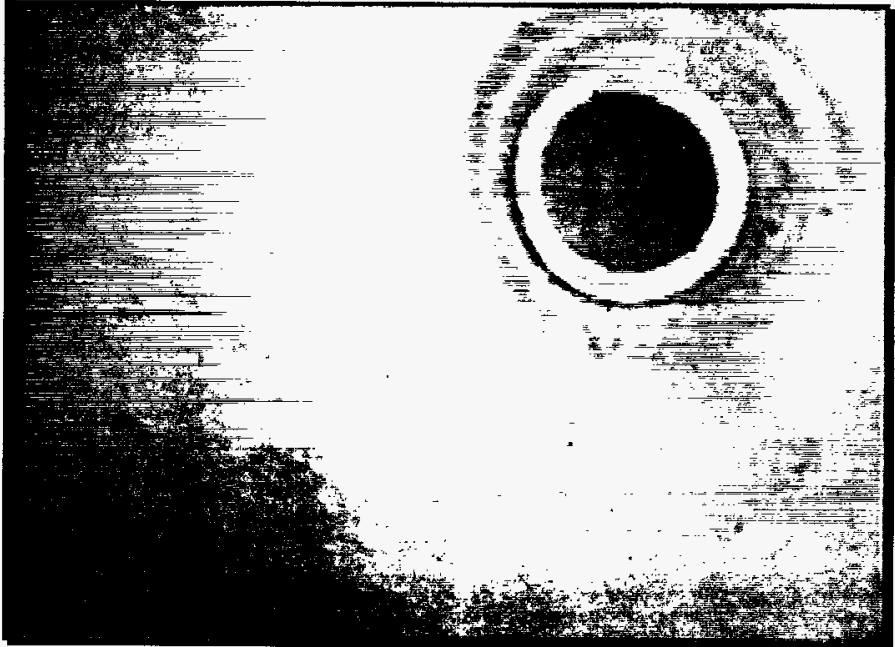

FIGURE 6.2.18 WESF Pool Cell 9 Liner Drain Grid Outfall Pipe 
Rev. 0

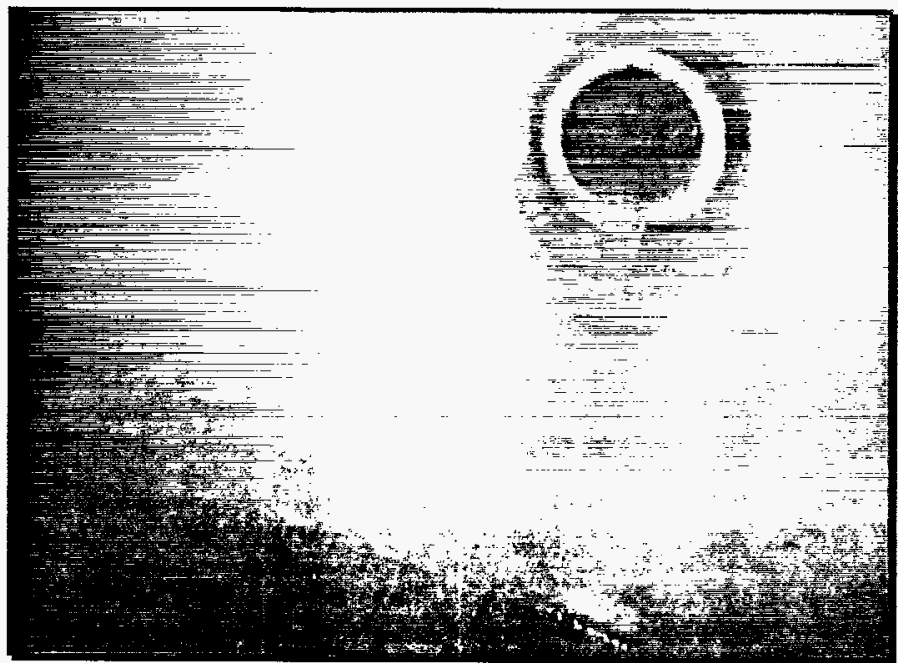

FIGURE 6.2.19 WESF Pool Cell 10 Sump Overall View

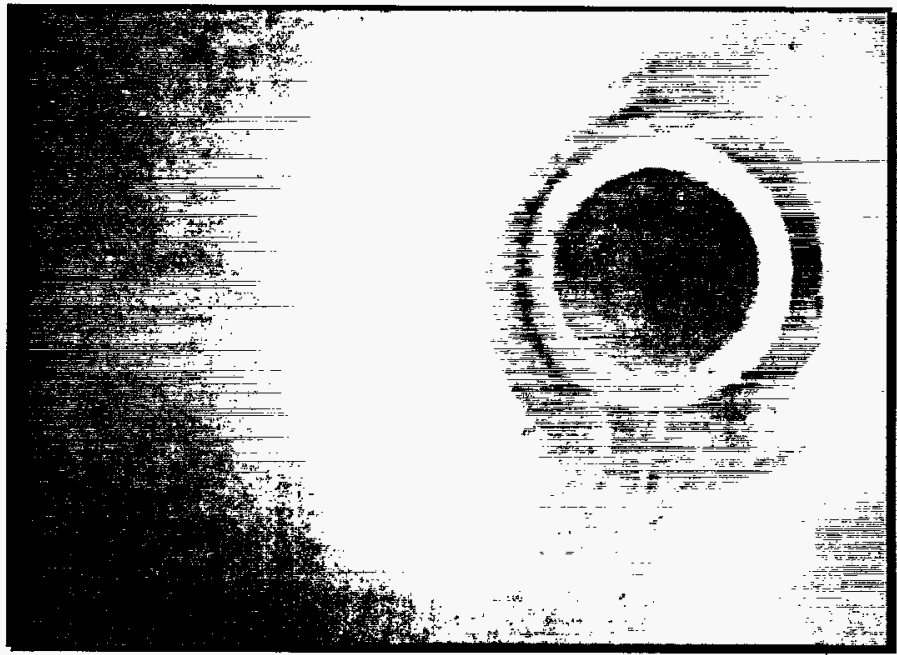

FIGURE 6.2.20 WESF Pool Cell 10 Liner Drain Grid Outfall Pipe 
Rev. 0

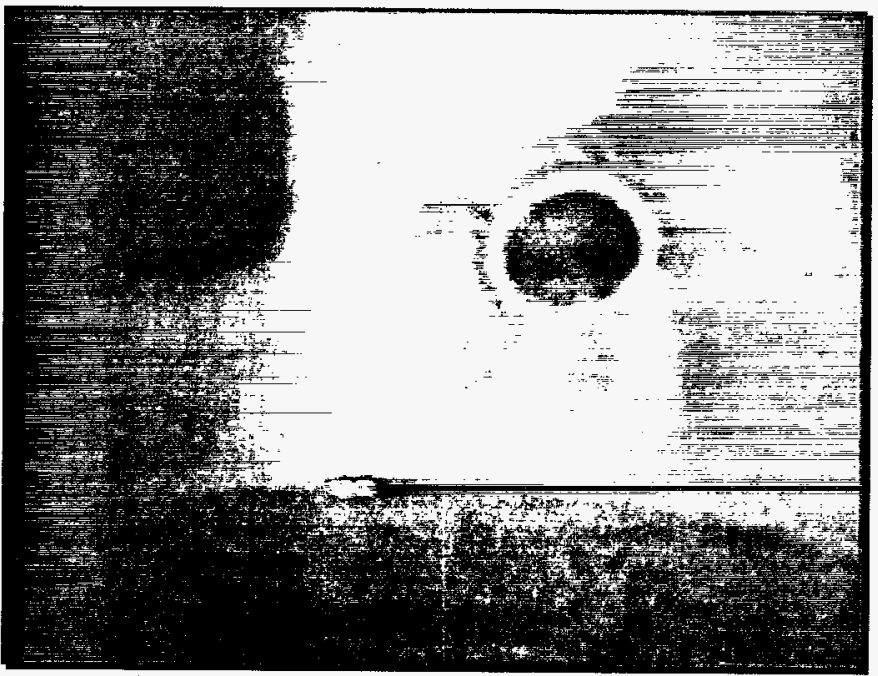

FIGURE 6.2.21 WESF Pool Cell 11 Sump Overall View

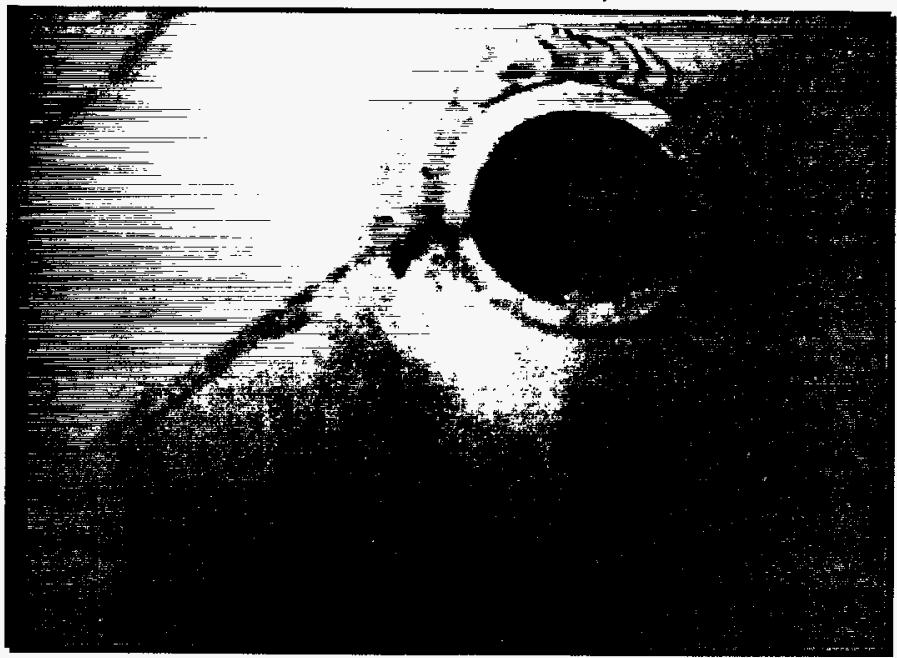

FIGURE 6.2.22 WESF Pool Cell 11 Liner Drain Grid Outfall Pipe 
Rev. 0

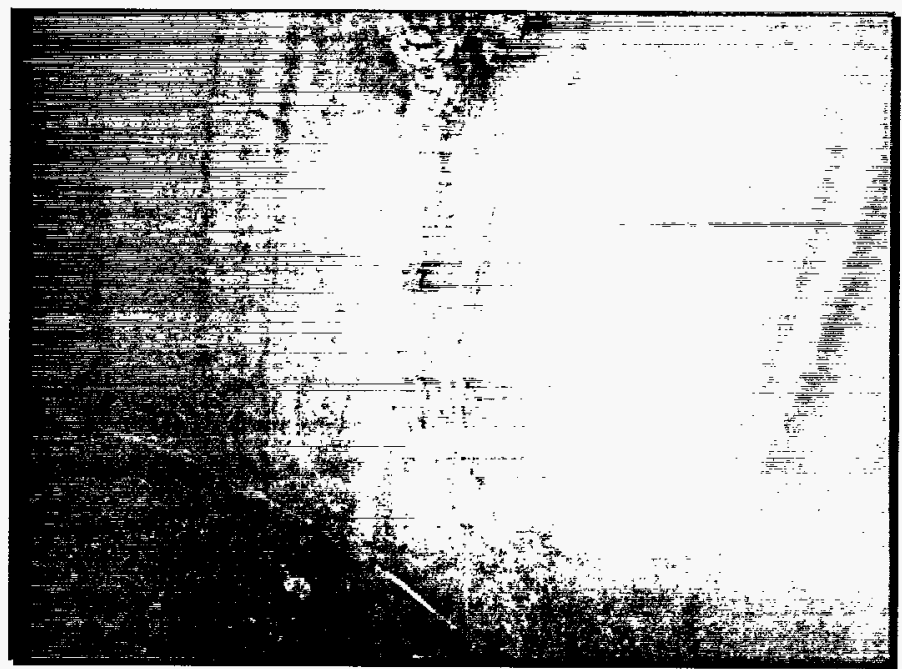

FIGURE 6.2.23 WESF Pool Cell Sump 12-1 Overall View

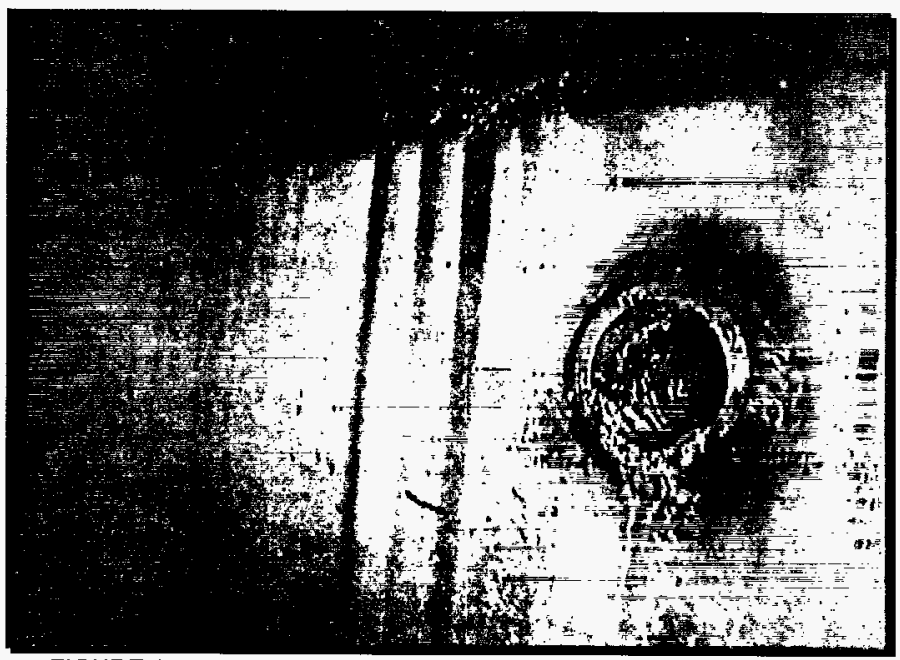

FIGURE 6.2.24 WESF Pool Cell Sump 12-1 Drain Grid Outfall Pipe 
Rev. 0

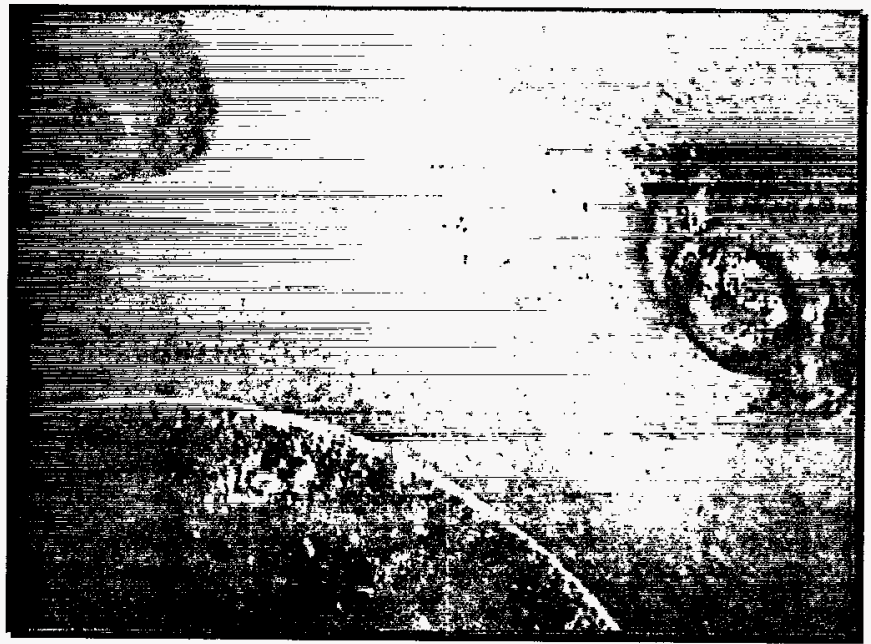

FIGURE 6.2.25 WESF Pool Cell Sump 12-2 Overall View

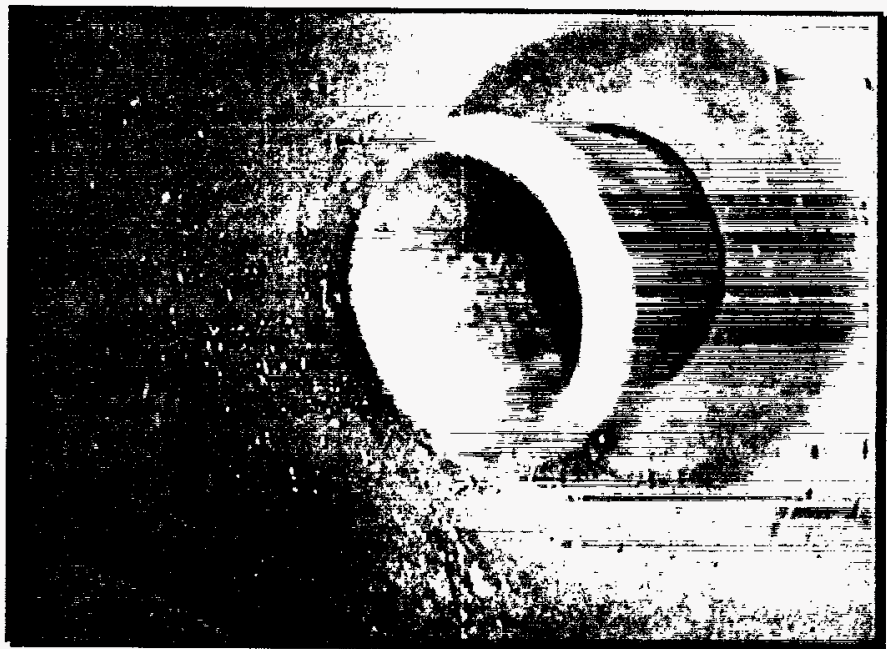

FIGURE 6.2.26 WESF Pool Cell Sump 12-2 Drain Grid Outfall Pipe From South Portion of Transfer Aisle 


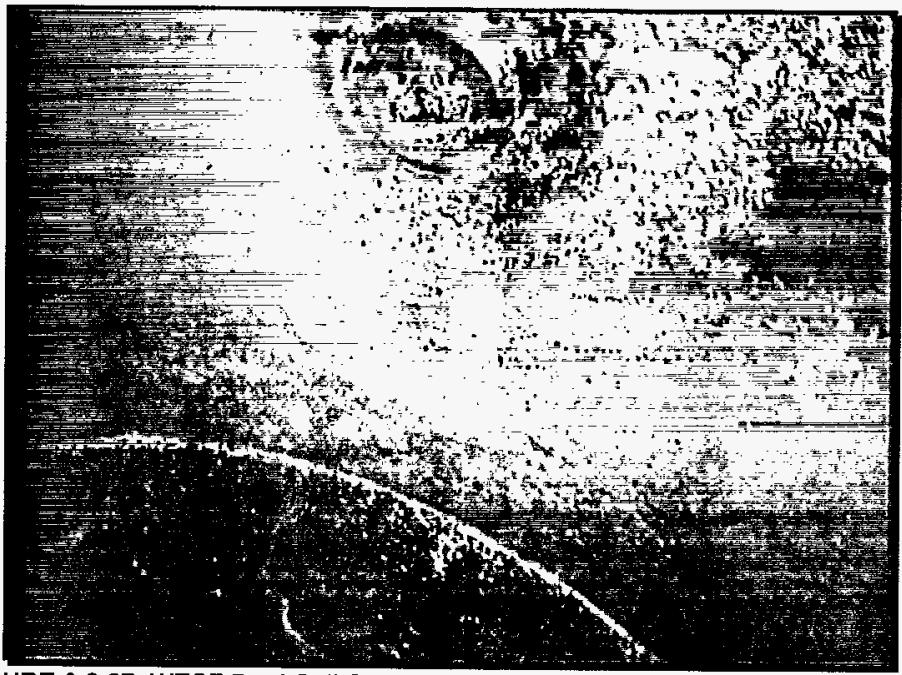

FIGURE 6.2.27 WESF Pool Cell Sump 12-2 Drain Grid Outfall Pipe From Cask Pit

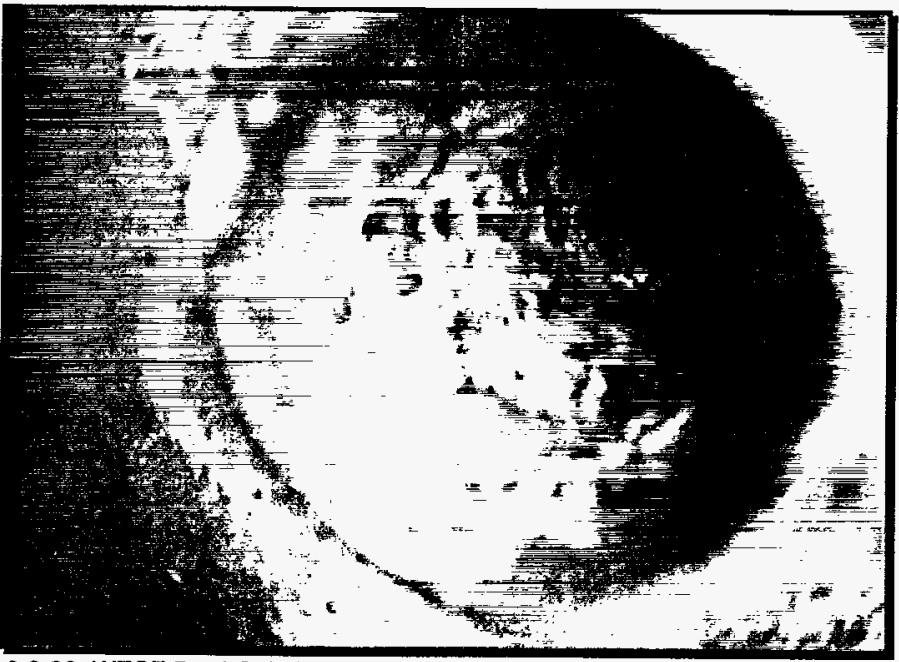

FIGURE 6.2.28 WESF Pool Cell Sump 12-2 Drain Grid Outfall Pipe From Cask Pit-Closeup 


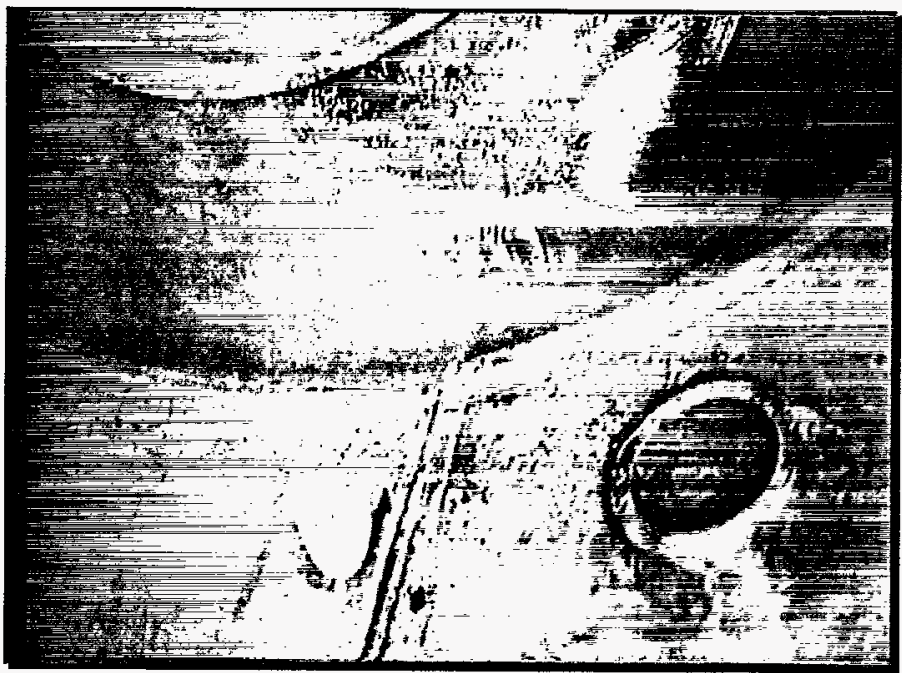

FIGURE 6.2.29 WESF Pool Cell 1 Sump Ceiling

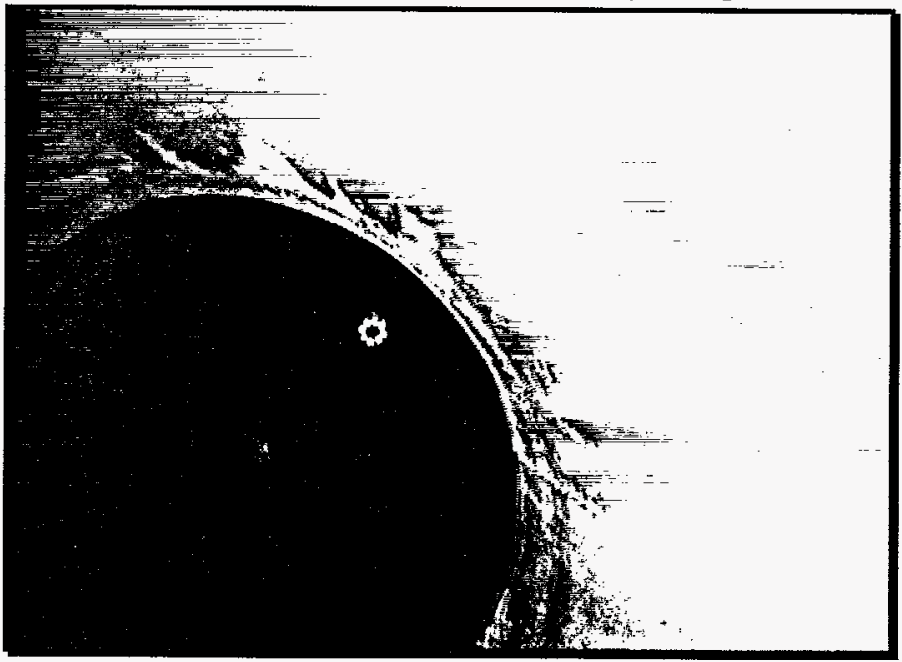

FIGURE 6.2.30 WESF Pool Cell 6 Bottom of 6rinch Leak Detector Riser 


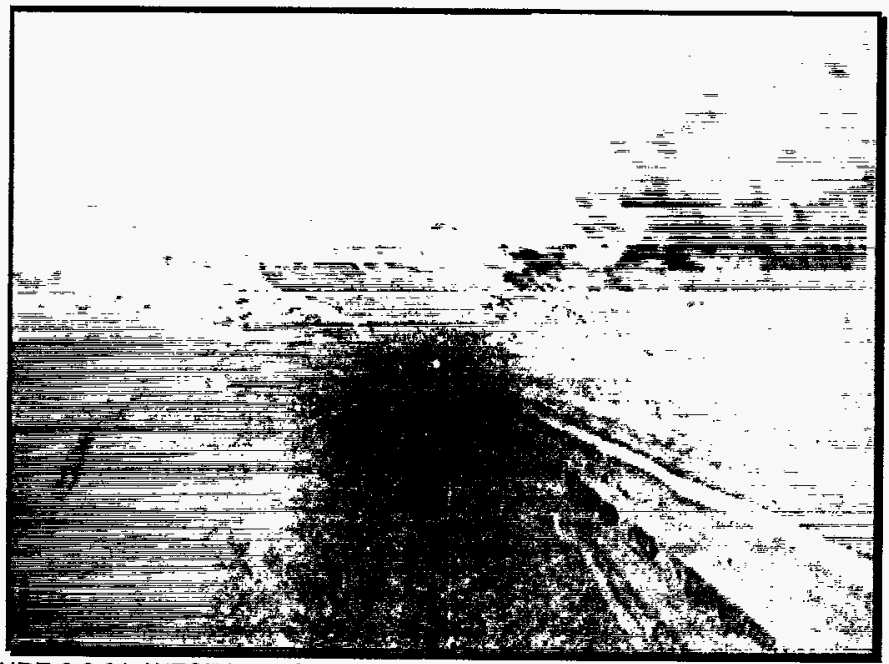

FIGURE 6.2.31 WESF Pool Cell 7 Top of 6-inch Leak Detector Riser (Downward)

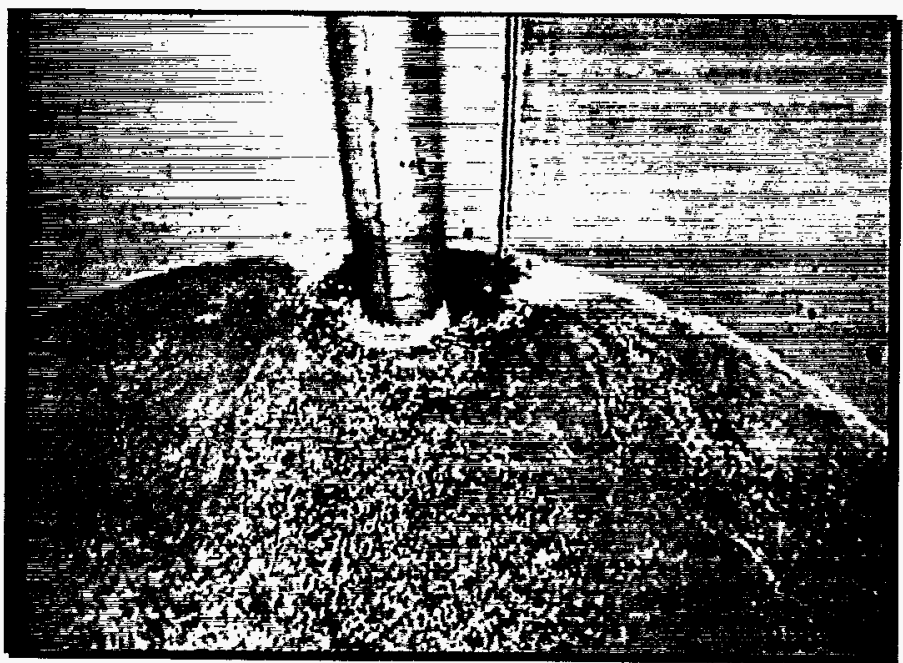

FIGURE 6.2.32 WESF Pool Cell Sump 12-2 Jet Out Line 


\subsection{Interviews with Plant Personnel}

The following pages document interviews with present and former WesF plant personnel. While it can be concluded that the leak has existed for a number of years, no precise start date can be pinpointed. 
Pool cell 5 sump History Questionnaire

Name: David A. Bruce

Position(s) at WeSF: Process engineering during design and start-up, process engineering manager until 1978.

When first noted pool cell 5 leak alarms: Not aware of any pool cell liner leaks at that time.

Action taken: None- not aware of any leaks or sump alarm problems.

How often PM was done in past on active \& inactive pools: No recollection.

Other observations: Pool cell liners leaked when first installed. Construction engineer Mike Fatur developed the method used for identifying the leak locations so that weld repairs could be made. Water containing a fluoregcent indicating dye was added to the leak detection riser while the water level in the pool cell was slowly brought up. The water level in the leak detection riser was maintained about a foot higher than that in the pool in order to provide a driving force to propel dye from the leak detection riser into the pool cell. Leaks showed up as jets of colored liquid, and were marked for subsequent weld repair. This was repeated until no leaks could be detected. 


\section{Name: Chuck Clemmons}

Position(s) at WESF: Instrument technician at WESF october 1977 until 1984. Instrument manager for B Plant/WESF until 1985. Project management 1985 until 1991. Maintenance planner 1991 until present.

When first noted pool cell 5 leak alarms: pool cell 5 alarm was always difficult to clear after performing PM. Alarm often re-appeared a few hours, shifts, or days later.

Action taken: Alarm was cleared by jetting the sump. Suspected that the cause was run-back from the jet. Once cleared by repeated jetting, the alarm would stay clear. If the detector alarmed between PM' $\theta$, the alarm would be cleared without instrument craft involvement.

How often PM was done in past on active \& inactive pools: Was already being done every 6 months when he began working at WESF in 1978 . Probably didn't do pool cell 7 and 8 sumps at first. Did do sumps 9 and 10 , not sure about 11; probably did it, too. At first the PM was performed by instrument technicians. The PM was transferred to electricians in $1980^{\prime} \mathrm{g}$ because of the voltage (300V) applied to the sensing electrodes.

other observations: The sump sometimes had to be jetted up to 3 days in a row to get the alarm to stay off. Don't remember teating pipe trench sump. 
Pool Cell 5 Sump History Questionnaire

Name: Gary L. Johnson

Position(s) at WESF: Operator since March 22, 1975

When first noted pool cell 5 leak alarms: No recollection of pool cell 5 leak alarms.

Action taken: N/A

How often PM was done in past on active \& inactive pools: Does not recall. Other observations: 


\section{Pool Cell 5 Sump History Questionnaire}

Name: Penny G. Purdy

Position(s) at WESF: Operator, 1975 to present.

When first noted pool cell 5 leak alarms: Noticed gradual decrease in pool cell 5 \& 6 weight factors since 1980 or 1981. The pool cell 5 leak alarm does not stand out in memory; if it went off, it would have been cleared by jetting. Possibly may have been tested more often in the past. The light went off when jetted, so it was not considered a problem.

Action taken: If it went off, it would have been jetted.

How often PM was done in past on active \& inactive pools: Possibly quarterly, not sure now.

Other observations: Recalls doing all the sumps during PM's. Only personally did it a couple of times. 
Pool Cell 5 Sump History Questionnaire

Name: Glenn L. Garman

Position(s) at WESF: Operator since $7 / 22 / 75$

When first noted pool cell 5 leak alarms: Recalls it going off occasionally, but does not remember specifically when it might have started, nor how often.

Action taken: Recalls jetting pool cell 5 sump to clear within the last few years.

How often PM was done in past on active \& inactive pools: Not sure, but thinks we may have just done the active pools at first.

other observations: 


\section{Pool Cell 5 sump History Questionnaire}

Name: William B. Cook

Position(s) at WESF: Operator

When first noted pool cell 5 leak alarms: A long time ago, had trouble with alarm.

Action taken: Doesn't remember it having to be jetted. Bill has never personally jetted pool cell 5 sump.

How often PM was done in past on active \& inactive pools: Just tested the active pool sumps at first.

Other observations: The alarm sometimes activated intermittently, and would sometimes clear on its own after a while. 


\section{Pool Cell 5 Sump History Questionnaire}

Name: James E. Wabaunsee

Position(s) at WESF: Operator 1975 to 1987, and 1988 to present.

When first noted pool cell 5 leak alarms: May have occurred occasionally, perhaps since 1988 .

Action taken:

How often PM was done in past on active \& inactive pools: Every 6 months. Other observations: 
Pool Cell 5 Sump History Questionnaire

Name: Daniel H. Barnett

Position(s) at WESF: Operator, 1978 to present.

When first noted pool cell 5 leak alarms: Does not recall trouble with it.

Action taken:

How often PM was done in past on active \& inactive pools: quarterly or biannually.

Other observations: 


\section{Pool Cell 5 Sump History Questionnaire}

\section{Name: Kathy Burton}

Position(s) at WESF: Operator 1980-1981, operations shift manager 19811986, and operations shift manager 1989-1995.

When first noted pool cell 5 leak alarms: Recalls that pool cell 5 was in alarm when she arrived at WESF in March, 1980. As an operator newly assigned to the facility, she noticed and inquired about this persistent alarm.

Action taken: Questioned why it was in alarm. Was advised not to worry about it, the assumption being that it was a nuisance alarm caused by some sort of instrument malfunction. It cleared whenever the sump was jetted.

How often PM was done in past on active \& inactive pools: Not sure, annually or every 6 months.

other observations: The pool cell 5 sump seemed to be in the alarm state the majority of the time. It would clear for a while after being jetted, then return to its customary alarm condition. 